Prepared in cooperation with the Central Texas Groundwater Conservation District

\title{
Streamflow Gains and Losses in the Colorado River in Northwestern Burnet and Southeastern San Saba Counties, Texas, 2012-14
}

Scientific Investigations Report 2015-5098

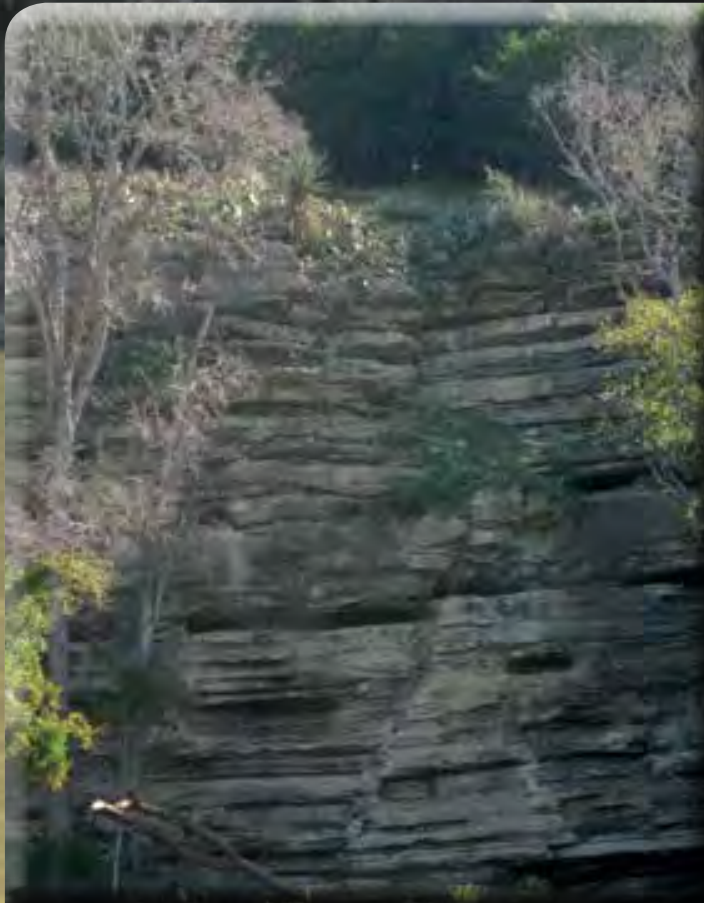




\section{Front cover:}

Backgound, Seeps along limestone outcrop downstream from where Jim John Creek flows into the Colorado River, October 31, 2012 (photograph by Jennifer Wilson, U.S. Geological Survey).

Bottom right, Faulting in limestone outcrop downstream from where Greenwood Creek flows into the Colorado River, October 31, 2012 (photograph by Jennifer Wilson, U.S. Geological Survey).

\section{Back cover:}

Backgound, Travertine deposits near site 4 (Post Oak Falls near Tow, Texas, October 31, 2012) (photograph by Jennifer Wilson, U.S. Geological Survey).

Top right, Wading discharge measurement made using the U.S. Geological Survey midsection method at site 1 (Colorado River downstream from Yancey Creek near Tow, Texas, December 3, 2012) (photograph by Christopher Braun, U.S. Geological Survey).

Top left, Concurrent discharge measurements made with extended wading rods using the U.S.

Geological Survey midsection method at site 5 (Colorado River at confluence of Jennings Creek near Tow, Texas), December 4, 2012 (photograph by Christopher Braun, U.S. Geological Survey). 


\section{Streamflow Gains and Losses in the Colorado River in Northwestern Burnet and Southeastern San Saba Counties, Texas, 2012-14}

By Christopher L. Braun and Scott D. Grzyb

Prepared in cooperation with the Central Texas Groundwater Conservation District

Scientific Investigations Report 2015-5098 


\title{
U.S. Department of the Interior SALLY JEWELL, Secretary
}

\section{U.S. Geological Survey \\ Suzette M. Kimball, Acting Director}

\author{
U.S. Geological Survey, Reston, Virginia: 2015
}

For more information on the USGS - the Federal source for science about the Earth, its natural and living resources, natural hazards, and the environment—visit http://www.usgs.gov or call 1-888-ASK-USGS.

For an overview of USGS information products, including maps, imagery, and publications, visit http://www.usgs.gov/pubprod/.

Any use of trade, firm, or product names is for descriptive purposes only and does not imply endorsement by the U.S. Government.

Although this information product, for the most part, is in the public domain, it also may contain copyrighted materials as noted in the text. Permission to reproduce copyrighted items must be secured from the copyright owner.

Suggested citation:

Braun, C.L., and Grzyb, S.D., 2015, Streamflow gains and losses in the Colorado River in northwestern Burnet and southeastern San Saba Counties, Texas, 2012-14: U.S. Geological Survey Scientific Investigations Report 2015-5098, 32 p., http://dx.doi.org/10.3133/sir20155098.

ISSN 2328-0328 (online) 


\section{Contents}

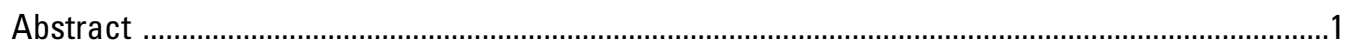

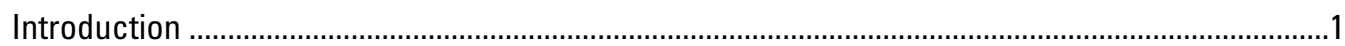

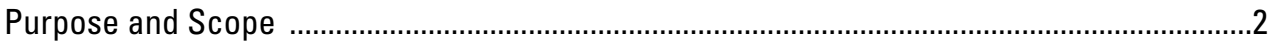

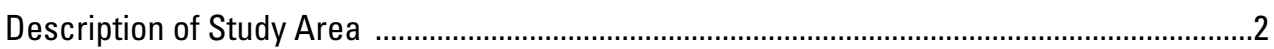

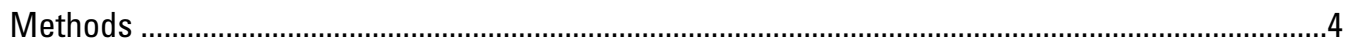

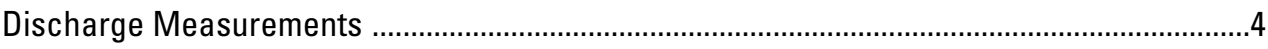

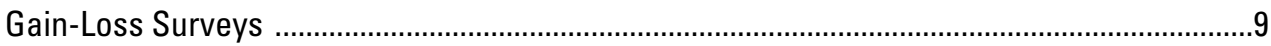

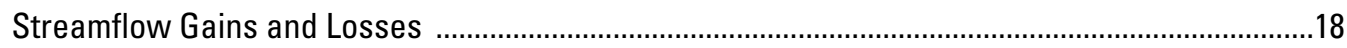

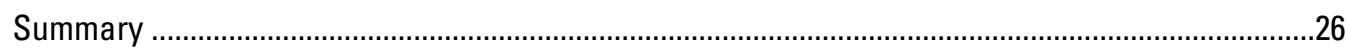

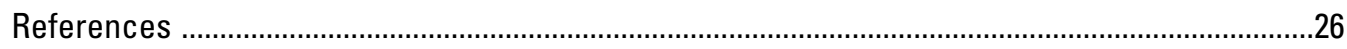

Appendixes

1. Calculation of estimated evaporative losses within reaches on the Colorado River in northwestern Burnet County, Texas, December 3-6, 2012 .................................31

2. Calculation of estimated evaporative losses within reaches on the Colorado River in northwestern Burnet County, Texas, May 31-June 1, 2014 .............................32

\section{Figures}

1. Map showing location of study area, northwestern Burnet and southeastern San Saba Counties, Texas

2. Diagram showing geologic and hydrogeologic units in northwestern Burnet and southeastern San Saba Counties, Texas

3. Map showing surficial geology in northwestern Burnet and southeastern San Saba Counties, Texas

4. Map showing hydrogeologic units and discharge measurement sites in northwestern Burnet and southeastern San Saba Counties, Texas

5. Photograph showing a tethered Acoustic Doppler current profiler (ADCP) boat ............9

6. Acoustic doppler current profiles made at the same location on $A$, May 31, 2014, at 5:35 p.m. and on $B$, June 1, 2014, at 10:41 a.m. at U.S. Geological Survey station 310022098273300 Colorado River at Post Oak Falls near Tow, Texas

7. Photographs of faults and hydrogeologic unit contacts along the Colorado River in northwestern Burnet and southeastern San Saba Counties, Texas, and a map depicting photograph locations. $A$, faulting within confining units (Point Peak Member and Morgan Creek Limestone); $B$, fault at contact between the MidCambrian aquifer and Ellenburger-San Saba aquifer; and $C$, fault in the Ellenburger-San Saba aquifer

8. Photographs of seeps, springs, and travertine deposits along the Colorado River in northwestern Burnet and southeastern San Saba Counties, Texas, and a map depicting photograph locations. $A$ and $C$, seeps; and $B$ and $D$, springs and associated travertine deposits

9. Photographs of tributary streams, which act as discharge points to the Colorado River in northwestern Burnet and southeastern San Saba Counties, Texas, and a map depicting photograph locations. $A$, Jim John Creek; $B$, Greenwood Creek; and $C$, Deer Creek 
10. Graphs showing river stage, instantaneous discharge, and cumulative precipitation at Lower Colorado River Authority streamflow-gaging station 1925 Colorado River at Bend, Texas, October 1, 2012-June 30, 2014

11. Graphs showing river stage and instantaneous discharge at Lower Colorado River Authority (LCRA) streamflow-gaging station 1925 Colorado River at Bend, Texas, November 30-December 9, 2012

12. Graphs showing river stage and instantaneous discharge at Lower Colorado River Authority (LCRA) streamflow-gaging station 1925 Colorado River at Bend, Texas, May 25-June 3, 2014

13. Schematic diagram of study area reaches showing streamflow-measurement sites and tributary inflows along the Colorado River in northwestern Burnet and southeastern San Saba Counties, Texas

14. Map showing reaches that were verifiably gaining or losing or unverifiably gaining or losing during the fall 2012 gain-loss survey in northwestern Burnet and southeastern San Saba Counties, Texas

15. Map showing reaches that were verifiably gaining or losing or unverifiably gaining or losing during the spring 2014 gain-loss survey in northwestern Burnet and southeastern San Saba Counties, Texas

\section{Tables}

1. Description of streamflow measurement sites on the Colorado River in northwestern Burnet and southeastern San Saba Counties, Texas, 2012-14

2. Reaches evaluated for streamflow gains or losses on the Colorado River in northwestern Burnet and southeastern San Saba Counties, Texas, 2012-14

3. Description of tributary inflows to the Colorado River in northwestern Burnet and southeastern San Saba Counties, Texas, 2012-14

4. Summary of gain-loss determinations for reaches on the Colorado River in northwestern Burnet and southeastern San Saba Counties, Texas, 2012-14

5. Summary of gain-loss determinations during the spring 2014 gain-loss survey for reaches on the Colorado River in northwestern Burnet and southeastern San Saba Counties, Texas, 2012-14 


\section{Conversion Factors}

Inch/Pound to International System of Units

\begin{tabular}{|c|c|c|}
\hline Multiply & By & To obtain \\
\hline \multicolumn{3}{|c|}{ Length } \\
\hline inch (in.) & 25.4 & millimeter (mm) \\
\hline foot (ft) & 0.3048 & meter (m) \\
\hline mile (mi) & 1.609 & kilometer (km) \\
\hline \multicolumn{3}{|c|}{ Flow Rate } \\
\hline cubic foot per second $\left(\mathrm{ft}^{3} / \mathrm{s}\right)$ & 0.02832 & cubic meter per second $\left(\mathrm{m}^{3} / \mathrm{s}\right)$ \\
\hline
\end{tabular}

\section{Datum}

Horizontal coordinate information is referenced to the North American Datum of 1983 (NAD 83).

Vertical coordinate information is referenced to the North American Vertical Datum of 1988

(NAVD 88).

\section{Abbreviations}

$\begin{array}{ll}\text { ADCP } & \text { Acoustic Doppler current profiler } \\ \text { CTGCD } & \text { Central Texas Groundwater Conservation District } \\ \text { LCRA } & \text { Lower Colorado River Authority } \\ \text { NWIS } & \text { National Water Information System } \\ \text { QA } & \text { Quality assurance } \\ \text { USGS } & \text { U.S. Geological Survey }\end{array}$





\title{
Streamflow Gains and Losses in the Colorado River in Northwestern Burnet and Southeastern San Saba Counties, Texas, 2012-14
}

\author{
By Christopher L. Braun and Scott D. Grzyb
}

\section{Abstract}

In October 2012, the U.S. Geological Survey (USGS), in cooperation with the Central Texas Groundwater Conservation District, began an assessment to better understand if and where groundwater from the Ellenburger-San Saba aquifer is discharging to the Colorado River, and if and where Colorado River streamflow is recharging the Ellenburger-San Saba aquifer in the study area. Discharge measurements were made to determine if different reaches of the Colorado River in northwestern Burnet and southeastern San Saba Counties are gaining or losing streamflow, the locations and quantities of gains and losses, and whether the gains and losses can be attributed to interaction between the river and the EllenbugerSan Saba aquifer. To assess streamflow gains and losses, two sets of synoptic gain-loss discharge measurements representing different streamflow conditions were completed. In the first gain-loss streamflow survey during December 3-6, 2012 (hereinafter the fall 2012 gain-loss survey), discharge measurements were made at low-flow conditions ranging from about 30 to 60 cubic feet per second $\left(\mathrm{ft}^{3} / \mathrm{s}\right)$ at seven locations along the Colorado River. In the second gain-loss streamflow survey during May 31-June 1, 2014 (hereinafter the spring 2014 gain-loss survey), discharge measurements were made at high-flow conditions ranging from about 660 to $900 \mathrm{ft}^{3} / \mathrm{s}$ at 12 locations along the Colorado River.

During the fall 2012 gain-loss survey, verifiable gains or losses of streamflow were identified in 4 of 6 reaches (the difference in measured discharge between the upstream and downstream boundaries of the reach was larger than the sum of potential errors associated with the two discharge measurements). The two reaches with a verifiable gain in streamflow cross areas where the Ellenburger-San Saba aquifer crops out. The more upstream of the two reaches with verifiable losses crosses a small part of the Ellenburger-San Saba aquifer outcrop and confining units (Point Peak Member and Morgan Creek Limestone); it is possible streamflow losses in this reach are in the form of recharge to the Ellenburger-San Saba aquifer; little streamflow is likely lost to the underlying formations in the downstream part of the reach, which consists of relatively impermeable aquifer confining units exposed at land surface. The more downstream of the two reaches where a verifiable loss of streamflow was measured also flows across relatively impermeable confining units before crossing the Mid-Cambrian aquifer outcrop in the lower part of the reach; most of the streamflow losses in this reach were likely a result of water infiltrating into the subsurface from the streambed and providing recharge to the relatively permeable MidCambrian aquifer.

During the spring 2014 gain-loss survey, 11 reaches were combined into 3 in an attempt to consolidate gains and losses as well as group reaches within the same hydrogeologic units. An unverifiable loss was measured in the reach farthest upstream, which crosses a combination of alluvium and Ellenburger-San Saba aquifer outcrop, whereas an unverifiable gain was measured in the middle reach, which crosses each of the different hydrogeologic units represented in the study area. The reach farthest downstream crosses an area where only the Ellenburger-San Saba aquifer crops out; a streamflow gain of $123 \mathrm{ft}^{3} / \mathrm{s}$ was measured in this reach, exceeding the potential error of $93.9 \mathrm{ft}^{3} / \mathrm{s}$. The verifiable streamflow gain in this downstream reach implies the Ellenburger-San Saba aquifer was discharging groundwater to the Colorado River in this part of the study area under the hydrologic conditions of the spring 2014 gain-loss survey.

\section{Introduction}

Assessments of whether a given reach gains or loses streamflow can provide insights into the nature of groundwater/surface-water interactions and can help to determine the quantity and quality of groundwater and surface water (Pinder and Celia, 2006). In the absence of appreciable tributary inflows or diversions of flow out of the channel, the question of whether a given reach gains or loses streamflow depends largely on groundwater/surface-water interactions. The relation between the altitude of the water table and the water-surface elevation of the stream referenced to an arbitrary datum (referred to as the river stage or stream stage) ultimately 
Streamflow Gains and Losses in the Colorado River in Northwestern Burnet and Southeastern San Saba Counties, Texas

determines whether a stream gains water from or loses water to the underlying aquifer, as described by Maurer and others (2006, p. 33):

If the streambed is sufficiently permeable to allow flow, streams lose flow and the infiltrating surface water recharges the underlying aquifer when the altitude of the water table adjacent to the stream is lower than the stream's stage. Conversely, when the altitude of the water table is higher than the stream's stage, ground-water discharge from the aquifer to the stream takes place and streams gain flow. Locations of streamflow gain and loss, and estimates of their rates, are useful for evaluating the effects of changes in land use and developing updated water budgets.

Groundwater recharge and groundwater withdrawals are important factors in determining whether a stream is gaining or losing in a given reach (Barlow and Leake, 2012). Groundwater recharge is dependent on factors such as climate, geology, soils, land-use practices (including irrigation effects), and depth to the water table (Healy and others, 2007); the distribution and extent of faults can also have an appreciable effect on groundwater recharge.

The interaction between the Ellenburger-San Saba aquifer and the Colorado River in northwestern Burnet and southeastern San Saba Counties in central Texas and the conditions under which the river gains or loses streamflow to the aquifer are not well understood. Accordingly, the U.S. Geological Survey (USGS), in cooperation with the Central Texas Groundwater Conservation District (CTGCD), completed a preliminary assessment to determine if the Ellenburger-San Saba aquifer is losing water to or gaining water from the Colorado River in northwestern Burnet and southeastern San Saba Counties under two different flow conditions, to gain a better understanding of the quantities of water entering or exiting the river if gaining or losing conditions are identified, and to identify reaches where groundwater enters or exits the river.

\section{Purpose and Scope}

This report provides a preliminary assessment of streamflow gains and losses along the Colorado River in northwestern Burnet and southeastern San Saba Counties in central Texas. Reaches were identified where streamflow gains and losses likely were occurring, along with the quantities of the gains and losses, and assessments were made as to whether the gains and losses were a result of the interaction of groundwater and surface water between the Ellenburger-San Saba aquifer and the Colorado River. In order to estimate streamflow gains and losses, two sets of synoptic streamflow discharge measurements were made representing different flow conditions. From these measurements, locations where discharge from and recharge to the Ellenburger-San Saba aquifer in northwestern Burnet and southeastern San Saba Counties were tentatively identified. Discharge measurements were made at seven locations along the Colorado River during the first gain-loss survey in December 3-6, 2012 (hereinafter the fall 2012 gain-loss survey). Discharge measurements were made at 12 locations along the Colorado River during the second gain-loss survey in May 31-June 1, 2014 (hereinafter the spring 2014 gainloss survey). The streamflow gains and losses documented in this report are specific to hydrologic regimes represented by the flow conditions measured during the fall 2012 and spring 2014 gain-loss surveys and are not suitable for broad characterization of streamflow gains and losses over all hydrologic regimes in the study area and should not be extrapolated over time.

\section{Description of Study Area}

The study area consists of a 10-mile (mi) segment of the Colorado River and selected tributaries (Spicewood Creek, Jennings Creek, Greenwood Creek, Jim John Creek, and Deer Creek) from Colorado Bend State Park (near the county line between Lampasas and Burnet Counties) to the upstream extent of Lake Buchanan (near the county line between San Saba and Llano Counties) in central Texas (fig. 1). The Colorado River forms the border between Burnet and San Saba Counties in the study area.

The Ellenburger-San Saba aquifer, which underlies much of the Colorado River in the study area, is composed of dolomite and marine limestone deposits of the San Saba Member of the Wilberns Formation (Cambrian) and the Ellenburger Group (Ordovician) (fig. 2). The Ellenburger Group includes the Honeycut, Gorman, and Tanyard Formations (from youngest to oldest), and the San Saba Member is the upper member of the Wilberns Formation; the surficial geology of the study area is shown in figure 3. The Ellenburger Group and the San-Saba Member are classified as a single aquifer (the Ellenburger-San Saba aquifer) because of their hydrologic interconnection and the difficulty in distinguishing the two stratigraphic units in the subsurface (fig. 2) (Berehe, 2005). The aquifer is highly faulted in the subsurface and at the surface and was partially eroded prior to being covered by Cretaceous sediments, causing large variations in aquifer thickness (Berehe, 2005). 


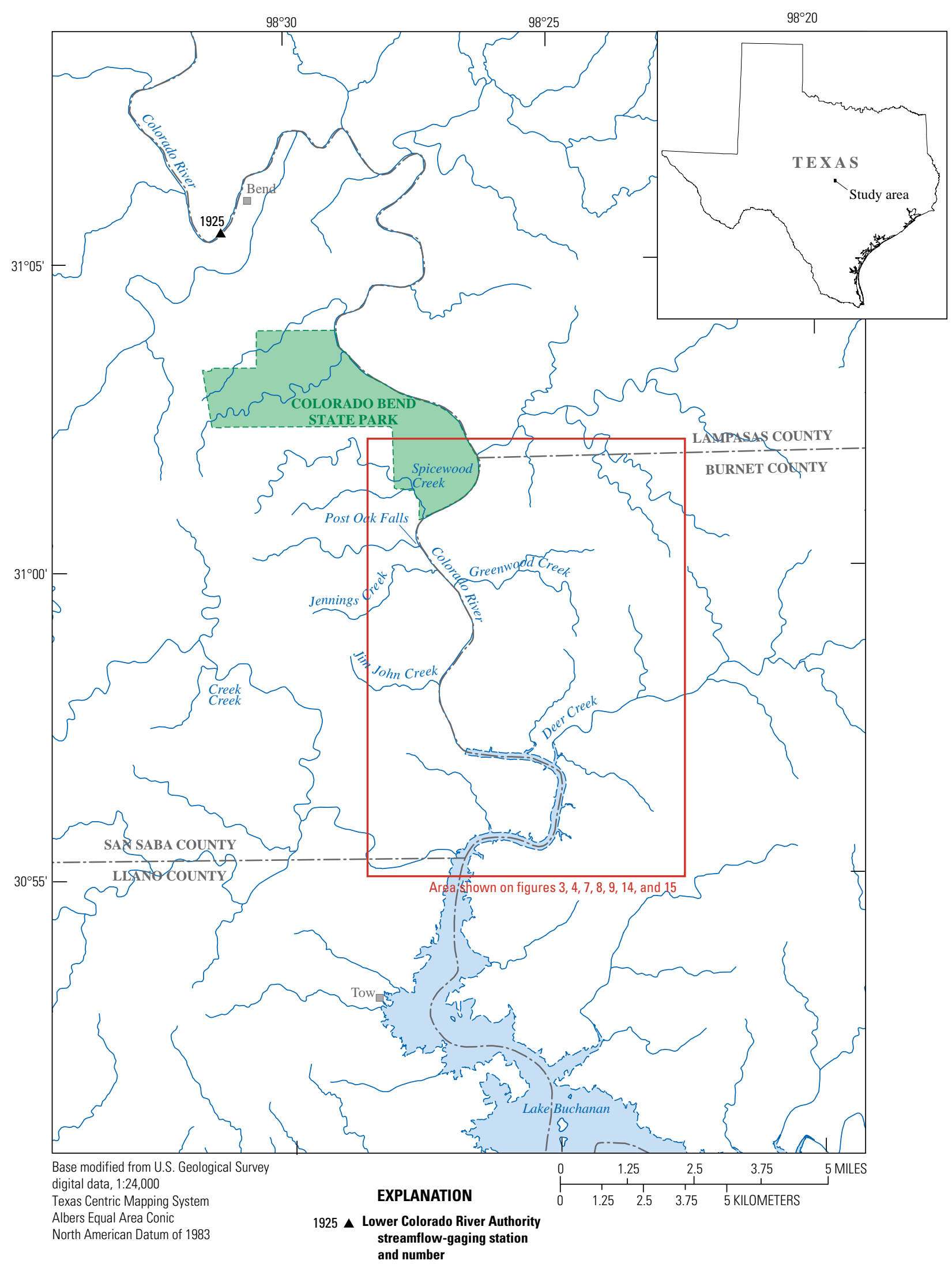

Figure 1. Location of study area, northwestern Burnet and southeastern San Saba Counties, Texas. 
Streamflow Gains and Losses in the Colorado River in Northwestern Burnet and Southeastern San Saba Counties, Texas

\begin{tabular}{|c|c|c|c|c|}
\hline \multirow{2}{*}{ System } & \multicolumn{3}{|c|}{ Geologic units } & \multirow{2}{*}{ Hydrogeologic units } \\
\hline & Group & Formation & Member & \\
\hline Quaternary & \multicolumn{2}{|c|}{ Pleistocene to recent flood plain } & Alluvium & localized alluvial aquifer \\
\hline \multirow{4}{*}{ Ordovician } & \multirow{4}{*}{ Ellenburger } & Honeycut & undivided & \multirow{5}{*}{ Ellenburger-San Saba aquifer } \\
\hline & & Gorman & undivided & \\
\hline & & \multirow{2}{*}{ Tanyard } & Staendebach & \\
\hline & & & Threadgill & \\
\hline \multirow{7}{*}{ Cambrian } & \multirow{7}{*}{ Moore Hollow } & \multirow{4}{*}{ Wilberns } & San Saba & \\
\hline & & & Point Peak & \multirow{2}{*}{$\begin{array}{l}\text { confining units (Point Peak Member } \\
\text { and Morgan Creek Limestone) }\end{array}$} \\
\hline & & & \multirow{2}{*}{$\begin{array}{c}\text { Morgan Creek } \\
\text { Limestone and Welge } \\
\text { Sandstone Members, } \\
\text { undivided }\end{array}$} & \\
\hline & & & & \multirow{2}{*}{$\begin{array}{l}\text { Mid-Cambrian aquifer (Welge } \\
\text { Sandstone and Lion Mountain } \\
\text { Sandstone) }\end{array}$} \\
\hline & & \multirow{3}{*}{$\begin{array}{l}\text { Oakville } \\
\text { Sandstone }\end{array}$} & \multirow{2}{*}{$\begin{array}{c}\text { Lion Mountain Sandstone } \\
\text { of Riley Formation } \\
\text { and Cap Mountain Limestone } \\
\text { Member of Riley Formation, } \\
\text { undivided }\end{array}$} & \\
\hline & & & & $\begin{array}{l}\text { confining unit (Cap } \\
\text { Mountain Limestone) }\end{array}$ \\
\hline & & & Hickory Sandstone & Hickory aquifer \\
\hline
\end{tabular}

Modified from Preston and others, 1996.

Figure 2. Geologic and hydrogeologic units in northwestern Burnet and southeastern San Saba Counties, Texas (modified from Preston and others, 1996).

\section{Methods}

Two streamflow gain-loss surveys were done in different seasons representing different hydrologic conditions-fall 2012 (December 3-6) at low-flow conditions and spring 2014 (May 31-June 1) at high-flow conditions-to accurately determine the seasonal variation, locations, and magnitude of groundwater/surface-water interactions. Synoptic discharge measurements on the Colorado River were made at 7 sites during the fall 2012 gain-loss survey (ranging from about 30 to 60 cubic feet per second [ $\left.\mathrm{ft}^{3} / \mathrm{s}\right]$ ) and at 12 sites during the spring 2014 gain-loss survey (ranging from about 660 to $900 \mathrm{ft}^{3} / \mathrm{s}$; fig. 4, table 1). Synoptic discharge measurements were also made on selected tributaries to gain a better understanding of streamflow gains and losses on the main stem of the Colorado River.

\section{Discharge Measurements}

Different methods of measuring discharge were used depending on flow conditions. For wading measurements, width and depth were physically measured by using a graduated tape and wading rod while the water velocity was measured with a hand-held acoustic Doppler velocimeter (SonTek, 2013) (hereinafter referred to as a "FlowTracker") attached to the wading rod. Wading discharge measurements were made by using the USGS midsection method (Young, 1950) where the depth and mean velocity are measured at vertical sounding stations; each vertical sounding station represents a subsection of the overall channel cross section. Abbreviated discharge measurements, consisting of fewer than 25 vertical soundings, were made at some wading sites on tributaries to the Colorado River because the channel cross section was too narrow to collect more than 24 vertical soundings. Full discharge measurements consisting of 25 to 30 vertical soundings were made at most wading sites. For both abbreviated and full discharge measurements, the summation of the discharges for all the subsections equaled the total discharge of the stream (Rantz and others, 1982). 

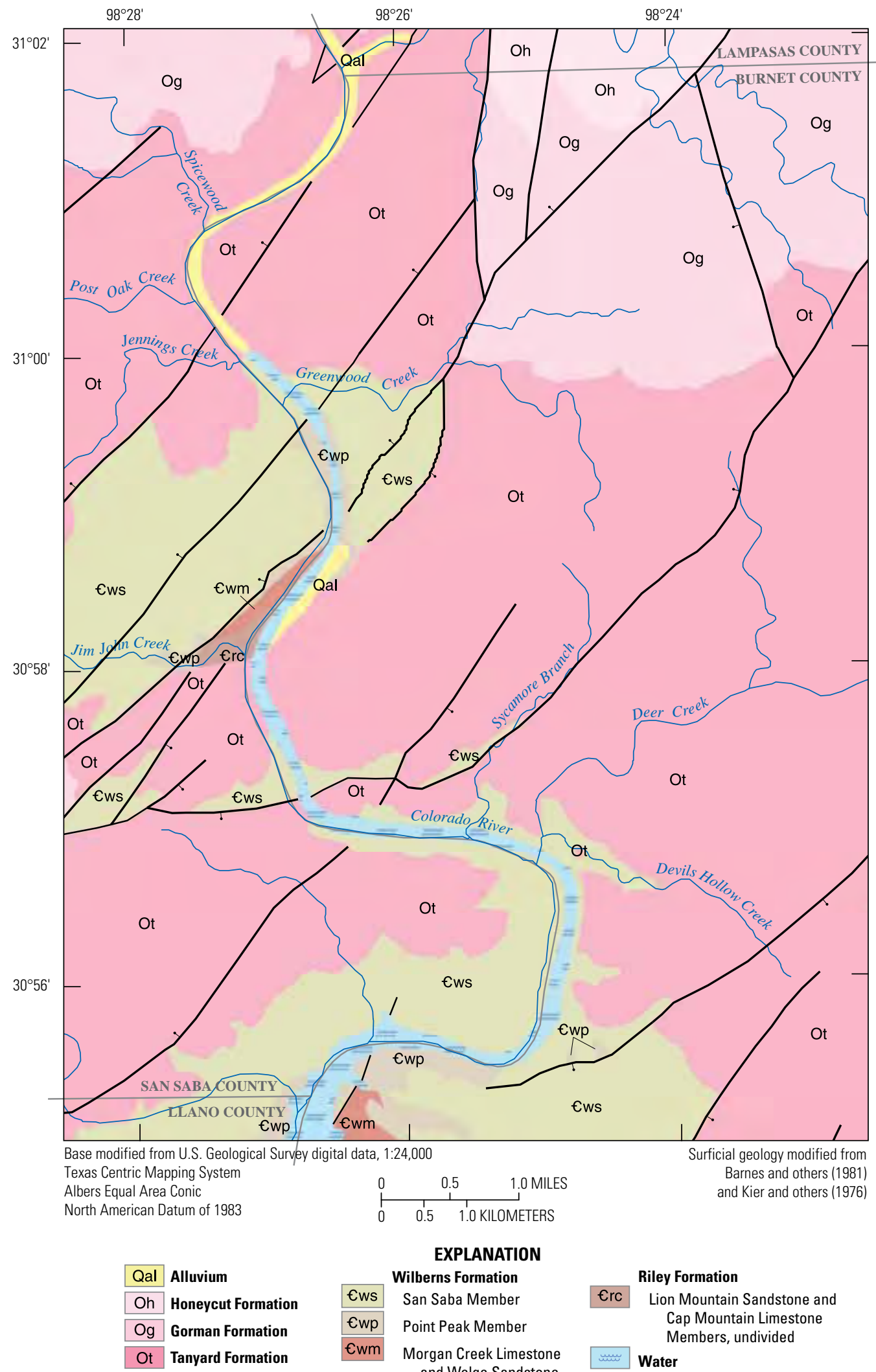

EXPLANATION

Wilberns Formation

San Saba Member

Point Peak Member

Morgan Creek Limestone and Welge Sandstone Members, undivided

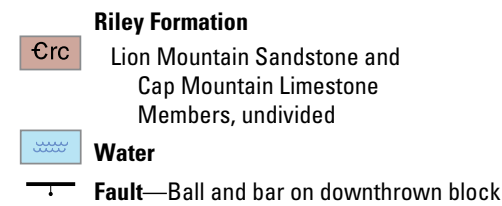

Figure 3. Surficial geology in northwestern Burnet and southeastern San Saba Counties, Texas. 


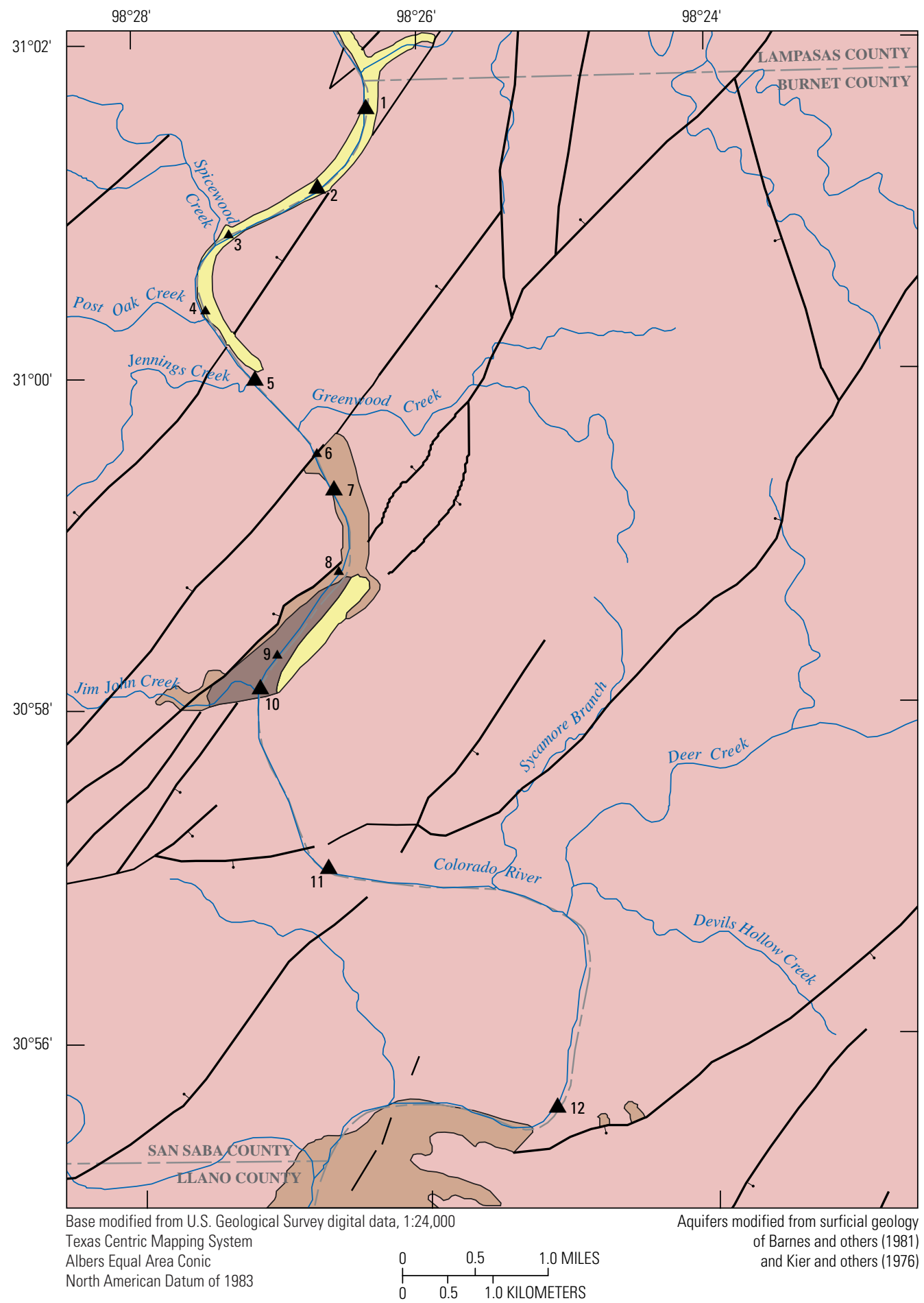

\section{Hydrogeologic units}

Alluvium

Ellenburger-San Saba

Confining units (Point Peak Member and Morgan Creek Limestone)
EXPLANATION

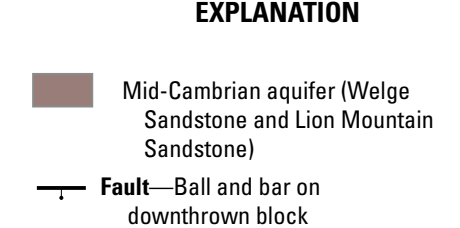

Streamflow-measurement site and number

${ }_{7}$ Measurements made during the fall 2012 (December 3-6, 2012) and spring 2014 (May 31-June 1, 2014) gain-loss surveys

g^ Measurements made only during the spring 2014 gain-loss survey (May 31-June 1, 2014)

Figure 4. Hydrogeologic units and discharge measurement sites in northwestern Burnet and southeastern San Saba Counties, Texas. 
Table 1. Description of streamflow measurement sites on the Colorado River in northwestern Burnet and southeastern San Saba Counties, Texas, $2012-14$.

[USGS, U.S. Geological Survey; ft $3 / \mathrm{s}$, cubic feet per second; FlowTracker, hand-held acoustic Doppler velocimeter (SonTek, 2013); G, good, measured discharge within 5 percent of the actual discharge ( 5 percent used for calculations in this report); $\mathrm{F}$, fair, measured discharge between 5 and 8 percent ( 8 percent used for calculations in this report); P, poor, measured discharge 8 percent greater or less than the actual discharge (10 percent used for calculations in this report); ADCP, acoustic Doppler current profiler; --, not measured]

\begin{tabular}{|c|c|c|c|c|c|c|c|c|}
\hline \multirow[b]{2}{*}{$\begin{array}{c}\text { Site } \\
\text { identifier } \\
\text { (fig. 4) }\end{array}$} & \multirow[b]{2}{*}{$\begin{array}{l}\text { USGS station } \\
\text { number }\end{array}$} & \multirow[b]{2}{*}{ USGS station name } & \multicolumn{6}{|c|}{ December 3-6, 2012 (fall 2012 gain-loss survey) } \\
\hline & & & $\begin{array}{c}\text { Individual } \\
\text { discharge } \\
\text { measurements } \\
\left(\mathrm{ft}^{3} / \mathrm{s}\right)\end{array}$ & $\begin{array}{c}\text { Average } \\
\text { measured } \\
\text { discharge } \\
\left(\mathrm{ft}^{3} / \mathrm{s}\right)\end{array}$ & $\begin{array}{l}\text { Instrument } \\
\text { used to } \\
\text { measure } \\
\text { discharge }\end{array}$ & $\begin{array}{c}\text { Date } \\
\text { measured }\end{array}$ & $\begin{array}{c}\text { Survey } \\
\text { measurement } \\
\text { error } \\
\text { ratings }\end{array}$ & $\begin{array}{l}\text { Potential error } \\
\text { associated with } \\
\text { discharge } \\
\text { measurement } \\
\left(\mathrm{ft}^{3} / \mathrm{s}\right)^{1}\end{array}$ \\
\hline 1 & 310134098262100 & $\begin{array}{l}\text { Colorado River downstream from Yancey } \\
\text { Creek near Tow, Tex. }\end{array}$ & $51.4,46.0$ & 48.7 & FlowTracker & December 3 & $\mathrm{~F}$ & 3.90 \\
\hline 2 & 310104098264900 & $\begin{array}{l}\text { Colorado River near Lemons Springs } \\
\text { Camp near Tow, Tex. }\end{array}$ & $47.9,45.8$ & 46.8 & FlowTracker & December 3 & $\mathrm{~F}$ & 3.74 \\
\hline 3 & 310049098272300 & $\begin{array}{l}\text { Colorado River at confluence of } \\
\text { Spicewood Creek near Tow, Tex. }\end{array}$ & -- & -- & -- & -- & -- & -- \\
\hline 4 & 310022098273300 & $\begin{array}{l}\text { Colorado River at Post Oak Falls near } \\
\text { Tow, Tex. }\end{array}$ & -- & -- & -- & -- & -- & -- \\
\hline 5 & 305958098271000 & $\begin{array}{l}\text { Colorado River at confluence of Jennings } \\
\text { Creek near Tow, Tex. }\end{array}$ & $52.9,59.4$ & 56.2 & FlowTracker & December 4 & $\mathrm{P}$ & 5.62 \\
\hline 6 & 305931098264400 & $\begin{array}{l}\text { Colorado River downstream from } \\
\text { Greenwood Creek near Tow, Tex. }\end{array}$ & -- & -- & -- & -- & -- & -- \\
\hline 7 & 305914098263600 & $\begin{array}{l}\text { Colorado River near Tanyard Crossing } \\
\text { near Tow, Tex. }\end{array}$ & $47.0,43.7$ & 45.4 & FlowTracker & December 4 & $\mathrm{P}$ & 4.54 \\
\hline 8 & 305850098263300 & $\begin{array}{l}\text { Colorado River downstream from Tanyard } \\
\text { Crossing near Tow, Tex. }\end{array}$ & -- & -- & -- & -- & -- & -- \\
\hline 9 & 305818098270300 & $\begin{array}{l}\text { Colorado River upstream from Jim John } \\
\text { Creek near Tow, Tex. }\end{array}$ & -- & -- & -- & -- & -- & -- \\
\hline 10 & 305807098271100 & $\begin{array}{l}\text { Colorado River at confluence of Jim John } \\
\text { Creek near Tow, Tex. }\end{array}$ & $31.9,27.4$ & 29.6 & FlowTracker & December 5 & $\mathrm{P}$ & 2.96 \\
\hline 11 & 305658098263900 & $\begin{array}{l}\text { Colorado River downstream from Jim John } \\
\text { Creek near Tow, Tex. }\end{array}$ & $43.1,32.9$ & 38.0 & FlowTracker & December 5 & $\mathrm{P}$ & 3.80 \\
\hline 12 & 305533098250900 & $\begin{array}{l}\text { Colorado River downstream from } \\
\text { Sycamore Creek near Tow, Tex. }\end{array}$ & $40.2,50.1$ & 45.2 & FlowTracker & December 6 & $\mathrm{P}$ & 4.52 \\
\hline
\end{tabular}


Table 1. Description of streamflow measurement sites on the Colorado River in northwestern Burnet and southeastern San Saba Counties, Texas, 2012-14.-Continued

[USGS, U.S. Geological Survey; $\mathrm{ft}^{3} \mathrm{~s}$, cubic feet per second; FlowTracker, hand-held acoustic Doppler velocimeter (SonTek, 2013); G, good, measured discharge within 5 percent of the actual discharge ( 5 percent used for calculations in this report); F, fair, measured discharge between 5 and 8 percent ( 8 percent used for calculations in this report); P, poor, measured discharge 8 percent greater or less than the actual discharge (10 percent used for calculations in this report); ADCP, acoustic Doppler current profiler; --, not measured]

\begin{tabular}{|c|c|c|c|c|c|c|c|}
\hline \multirow[b]{2}{*}{$\begin{array}{l}\text { Site } \\
\text { identifier } \\
\text { (fig. 4) }\end{array}$} & \multicolumn{7}{|c|}{ May 31-June 1, 2014 (spring 2014 gain-loss survey) } \\
\hline & $\begin{array}{l}\text { Discharge determined from two or } \\
\text { more transects (pass from one side of } \\
\text { stream to other by using an ADCP) } \\
\left(\mathrm{ft}^{3} / \mathrm{s}\right)\end{array}$ & $\begin{array}{l}\text { Average } \\
\text { measured } \\
\text { discharge } \\
\left(\mathrm{ft}^{3} / \mathbf{s}\right)\end{array}$ & $\begin{array}{l}\text { Instrument } \\
\text { used to } \\
\text { measure } \\
\text { discharge }\end{array}$ & $\begin{array}{c}\text { Date } \\
\text { measured }\end{array}$ & $\begin{array}{l}\text { Survey } \\
\text { measurement } \\
\text { error rating }\end{array}$ & $\begin{array}{l}\text { Potential error } \\
\text { associated } \\
\text { with discharge } \\
\text { measurement } \\
\left(\mathrm{ft}^{3} / \mathrm{s}\right)^{1}\end{array}$ & $\begin{array}{l}\text { Adjusted } \\
\text { discharge } \\
\left(\mathrm{ft}^{3} / \mathrm{s}\right)\end{array}$ \\
\hline 1 & ${ }^{2} 864,{ }^{2} 890$ & 877 & FlowTracker & May 31 & $\mathrm{P}$ & 87.7 & 892 \\
\hline 2 & 838, 833, 839, 838 & 837 & $\mathrm{ADCP}$ & May 31 & G & 41.8 & 853 \\
\hline 3 & $832,848,813,854$ & 837 & $\mathrm{ADCP}$ & May 31 & G & 41.8 & 835 \\
\hline 4 & ${ }^{3} 823,{ }^{3} 835 ;{ }^{4} 666,{ }^{4} 692$ & ${ }^{3} 829,{ }^{4} 679$ & ADCP & May 31 , June 1 & ${ }^{3} \mathrm{G},{ }^{4} \mathrm{G}$ & ${ }^{3} 41.4,{ }^{4} 34.0$ & ${ }^{3} 829,{ }^{4} 679$ \\
\hline 5 & 676,660 & 668 & $\mathrm{ADCP}$ & June 1 & G & 33.4 & 687 \\
\hline 6 & 706, 709 & 708 & $\mathrm{ADCP}$ & June 1 & G & 35.4 & 695 \\
\hline 7 & 707, 696 & 702 & $\mathrm{ADCP}$ & June 1 & G & 35.1 & 701 \\
\hline 8 & 694, 719 & 706 & $\mathrm{ADCP}$ & June 1 & G & 35.3 & 702 \\
\hline 9 & 710,730 & 720 & $\mathrm{ADCP}$ & June 1 & G & 36.0 & 721 \\
\hline 10 & 722, 787, 707, 786 & 750 & $\mathrm{ADCP}$ & June 1 & G & 37.5 & 716 \\
\hline 11 & 790,761 & 776 & $\mathrm{ADCP}$ & June 1 & G & 38.8 & 754 \\
\hline 12 & 707,704 & 706 & ADCP & June 1 & $\mathrm{~F}$ & 56.5 & 838 \\
\hline
\end{tabular}

The discharge measurement was multiplied by the percent difference assigned to the measurement rating to determine the potential error.

${ }^{2}$ Wading discharge measurements made by different hydrographers using a FlowTracker.

${ }^{3}$ Based on streamflow measurement made on May 31, 2014.

${ }^{4}$ Based on streamflow measurement made on June 1, 2014. 
During the fall 2012 gain-loss survey, all discharge measurements were made by using the midsection method of measuring discharge with the FlowTracker. At sites 1 and 2 , discharge was measured by wading in the stream with the FlowTracker attached to a wading rod; the stream was too deep to safely wade in fall 2012 at the remaining sites. At the sites where the stream was too deep to wade, an extended wading rod was lowered from an inflatable raft tethered to the banks at the predetermined discharge measurement locations. The inflatable raft was attached to a rope that extended across the channel, and two hydrographers ferried themselves across the channel while measuring discharge concurrently, one hydrographer on either side of the raft.

During the spring 2014 gain-loss survey, discharge at site 1 was again measured by using the midsection method with a FlowTracker while wading the stream. Because of high flows and unsuitable depths for wading measurements, a movingboat Acoustic Doppler current profiler (ADCP) method (Mueller and others, 2013) was used to collect discharge data at the remaining sites during the spring 2014 gain-loss survey. In the moving-boat ADCP method that was used, the discharge was measured by using an ADCP housed in a small (less than $4 \mathrm{ft}$ ) boat (fig. 5). The boat housing the ADCP was tethered to a rod extending from the bow of a larger manned boat powered by an outboard motor. In order to accurately measure discharge, the operator of the motorized boat made either two

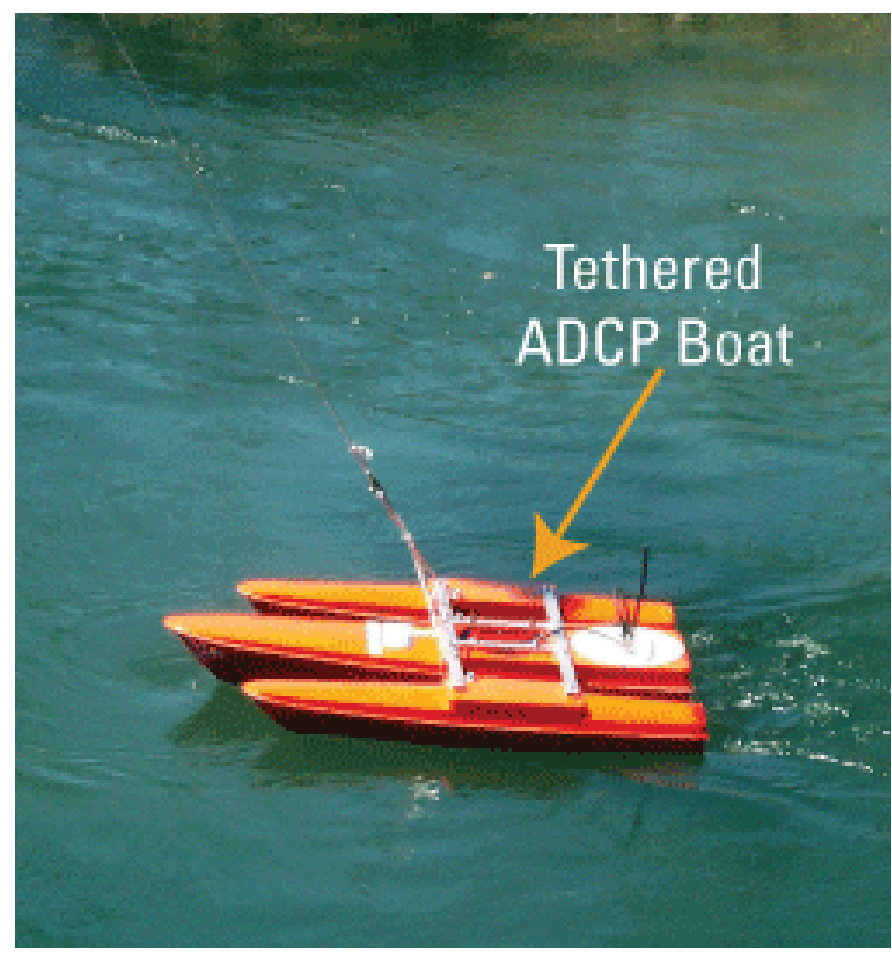

Figure 5. A tethered Acoustic Doppler current profiler (ADCP) boat (photograph by Geoffrey D. Cartano, U.S. Geological Survey, from Oberg and others, 2005). or four passes across the stream. The small boat moved freely in the water and orientated itself to the direction of the current as it collected acoustic data throughout the water column, which minimized directional bias in the measured discharge (Oberg and others, 2005). Additional details of the standard USGS protocols that were used for measuring discharge are described in Rantz and others (1982) and Turnipseed and Sauer (2010).

All discharge data collected using the ADCP were processed using WinRiver II software (Teledyne RD Instruments, 2007) and were recorded and calculated as data points with a two-dimensional XY planar position (channel width and depth) and a mean velocity magnitude and direction (fig. 6). In accordance with USGS standard methods, all moving-boat ADCP measurements consisted of an even number of transects (pass from one side of stream to other) made over a duration of at least 12 minutes (Mueller and others, 2013). In many instances, two passes were sufficient to meet the 12-minute duration limit; however, at sites 2,3 , and 10 , two additional passes (total of four) were made to meet the requirements to ensure that enough data were collected to adequately characterize streamflow conditions.

Quality assurance (QA) practices were followed to ensure the quality, precision, accuracy, and completeness of the discharge measurements and of the associated data pertaining to the discharge measurements. All digital data were reviewed by USGS Texas Water Science Center personnel to ensure proper documentation. Measurement field sheets were used to document proper operation and maintenance of equipment and collection of representative data. At least one duplicate discharge measurement was made at each site. All measured data were entered into the National Water Information System (NWIS) database (U.S. Geological Survey, 2015) and reviewed by USGS personnel following standard USGS procedures (Turnipseed and Sauer, 2010; Mueller and others, 2013).

\section{Gain-Loss Surveys}

Discharge measurement locations were selected for the gain-loss surveys (table 1) based on the locations of (1) hydrogeologic unit contacts (fig. 4); (2) faults (fig. 7); (3) seeps, springs, and travertine deposits (fig. 8); and (4) tributary inflows (fig. 9). Figures 4 and 7 illustrate the spatial location and extent of the hydrogeologic unit contacts and faults, respectively, that were used to select measurement locations in the study area. Measurement locations on the Colorado River were selected to bracket hydrogeologic units, where possible, in order to quantify gains and losses associated with the hydrogeologic units. Site 2 was selected downstream from a major fault (fig. 4) and just downstream from an area with known seeps (fig. 8). All of the reaches evaluated for streamflow gains or losses on the Colorado River in northwestern Burnet and southeastern San Saba Counties are depicted in table 2. 


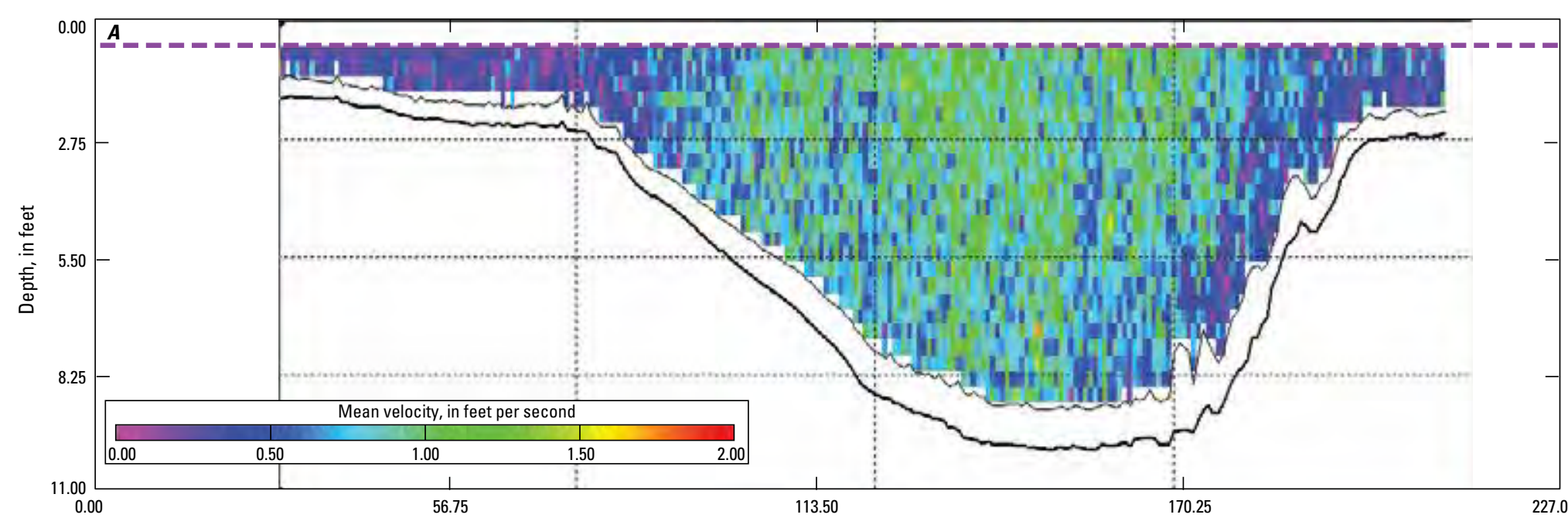

EXPLANATION

- - Top of velocity profile

_ Bottom of velocity profile

- Bottom of channel

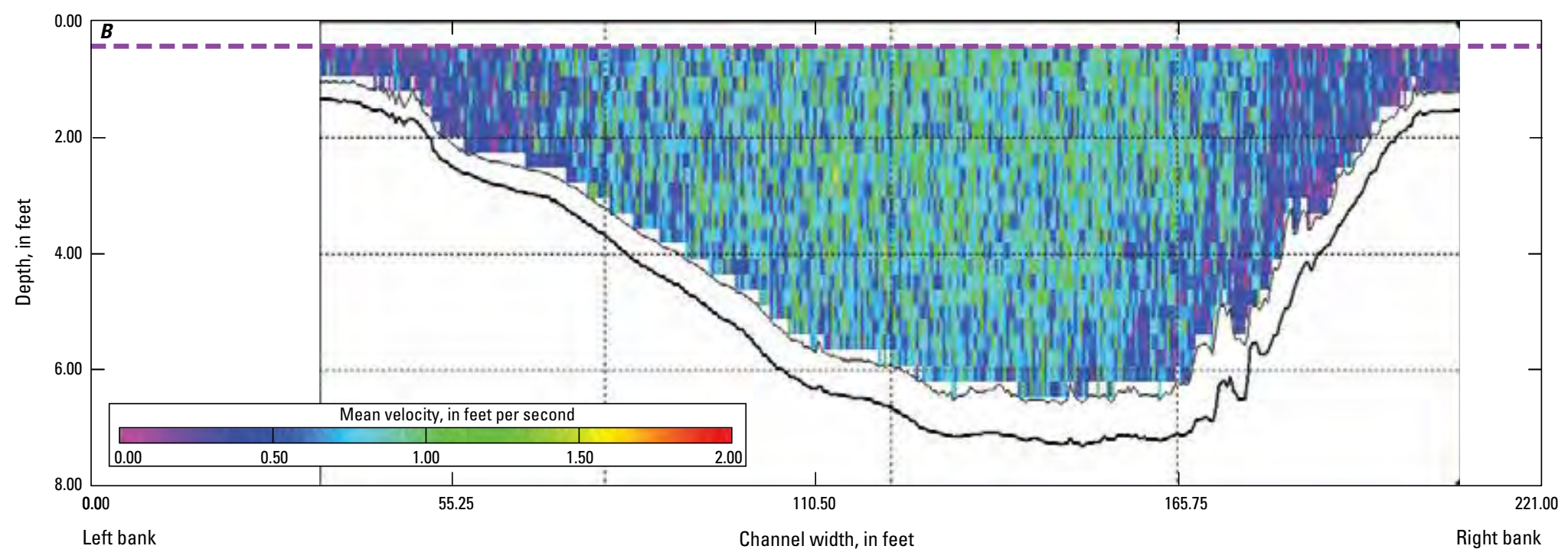

Figure 6. Acoustic doppler current profiles made at the same location on $A$, May 31, 2014, at 5:35 p.m. and on $B$, June 1, 2014, at 10:41 a.m. at U.S. Geological Survey station 310022098273300 Colorado River at Post Oak Falls near Tow, Texas. 


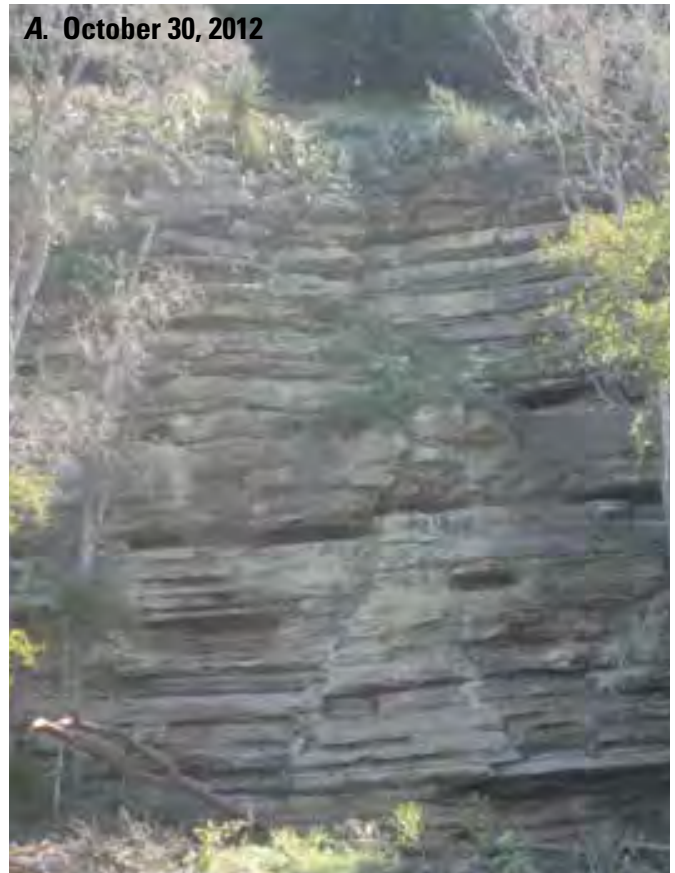

\section{October 30, 2012}

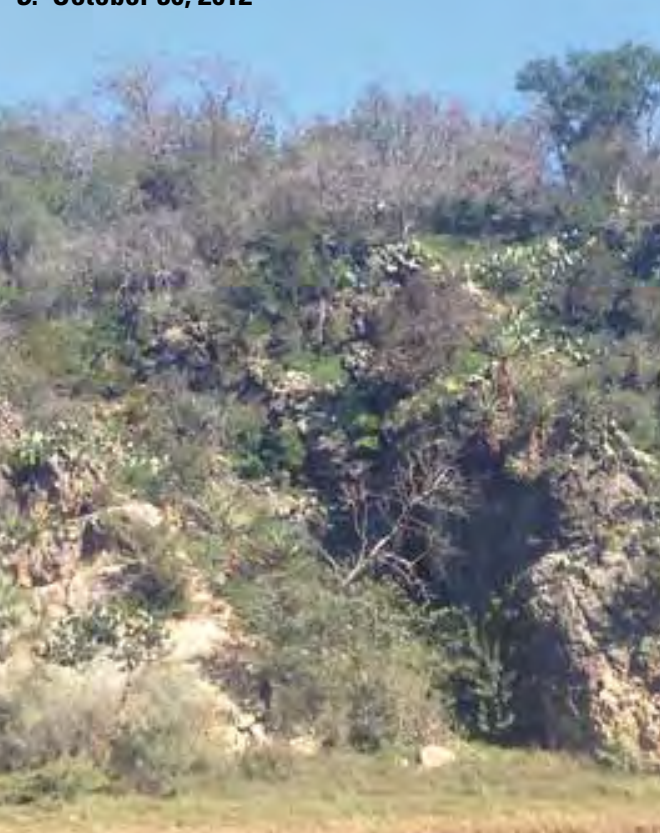

EXPLANATION

Hydrogeologic units

Alluvium

Ellenburger-San Saba

Confining units (Point Peak

Member and Morgan Creek Limestone)

Mid-Cambrian aquifer (Welge

Sandstone and Lion Mountain

Sandstone)

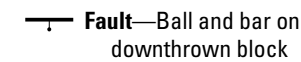

$\boldsymbol{A}-$ Location where photograph was taken-Arrow indicates approximate orientation of photograph

$\Delta$ Most upstream streamflow or downstream measurement site-USB, upstream; DSB downstream
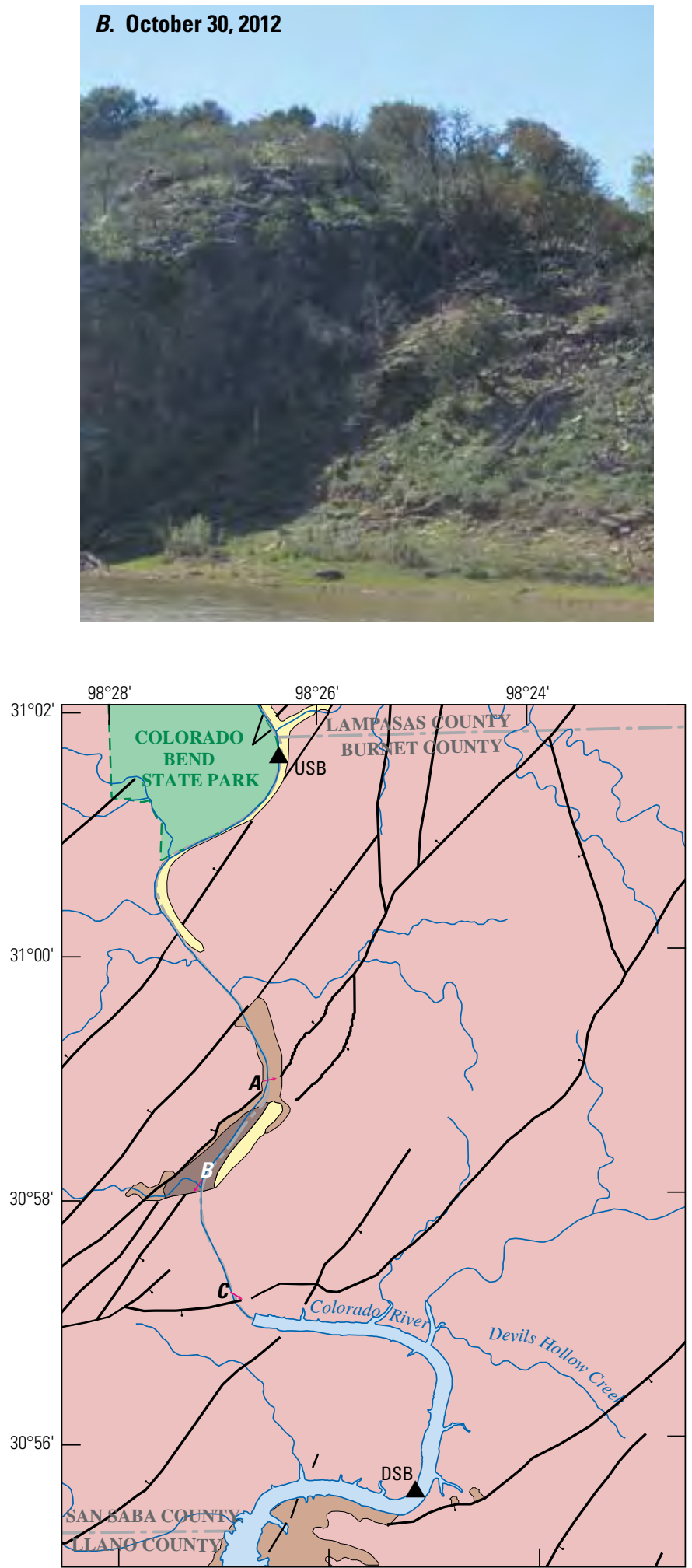

Base modified from U.S. Geological Survey digital data, 1:24,000

Texas Centric Mapping System

Albers Equal Area Conic

North American Datum of 1983

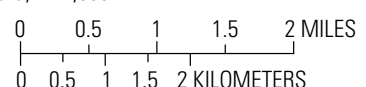

NOTE: Photograph labels correspond to map locations.

Figure 7. Faults and hydrogeologic unit contacts along the Colorado River in northwestern Burnet and southeastern San Saba Counties, Texas, and a map depicting photograph locations. $A$, faulting within confining units (Point Peak Member and Morgan Creek Limestone); $B$, fault at contact between the Mid-Cambrian aquifer and Ellenburger-San Saba aquifer; and $C$, fault in the Ellenburger-San Saba aquifer. 

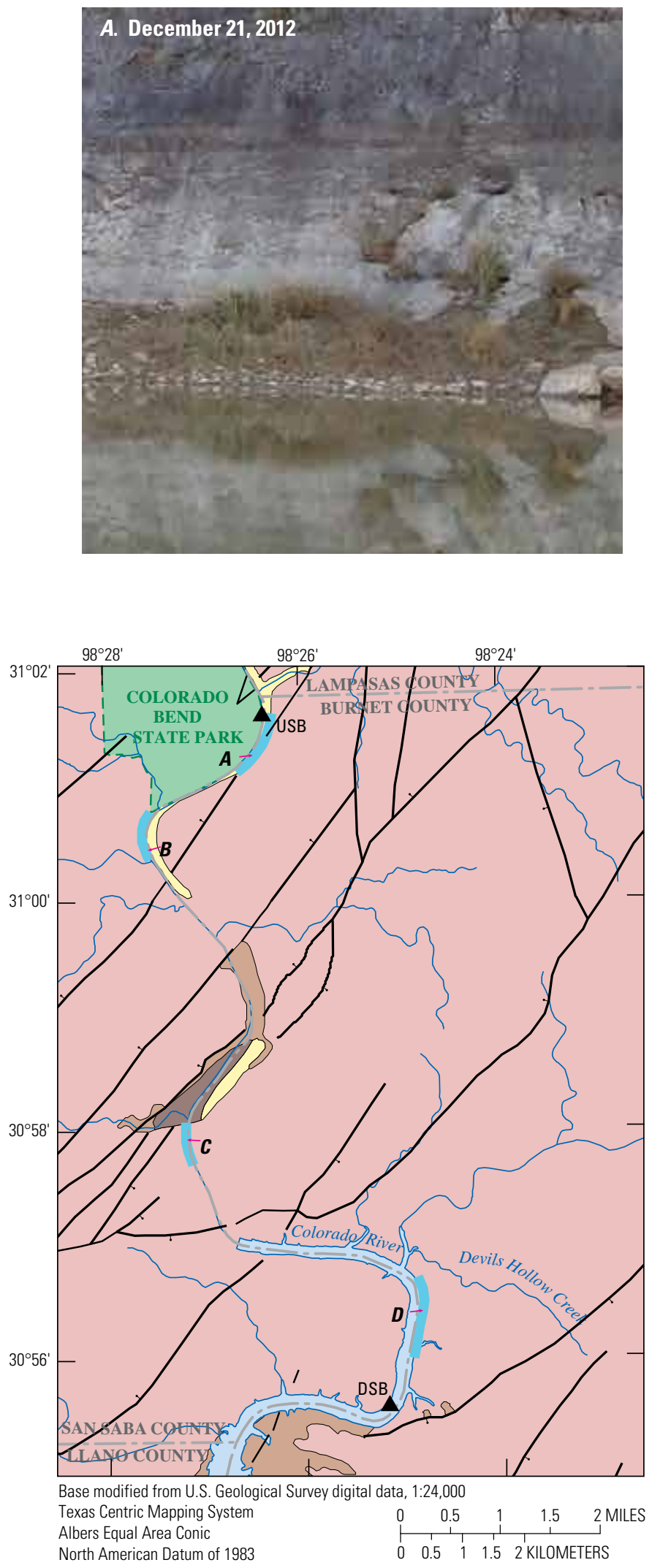
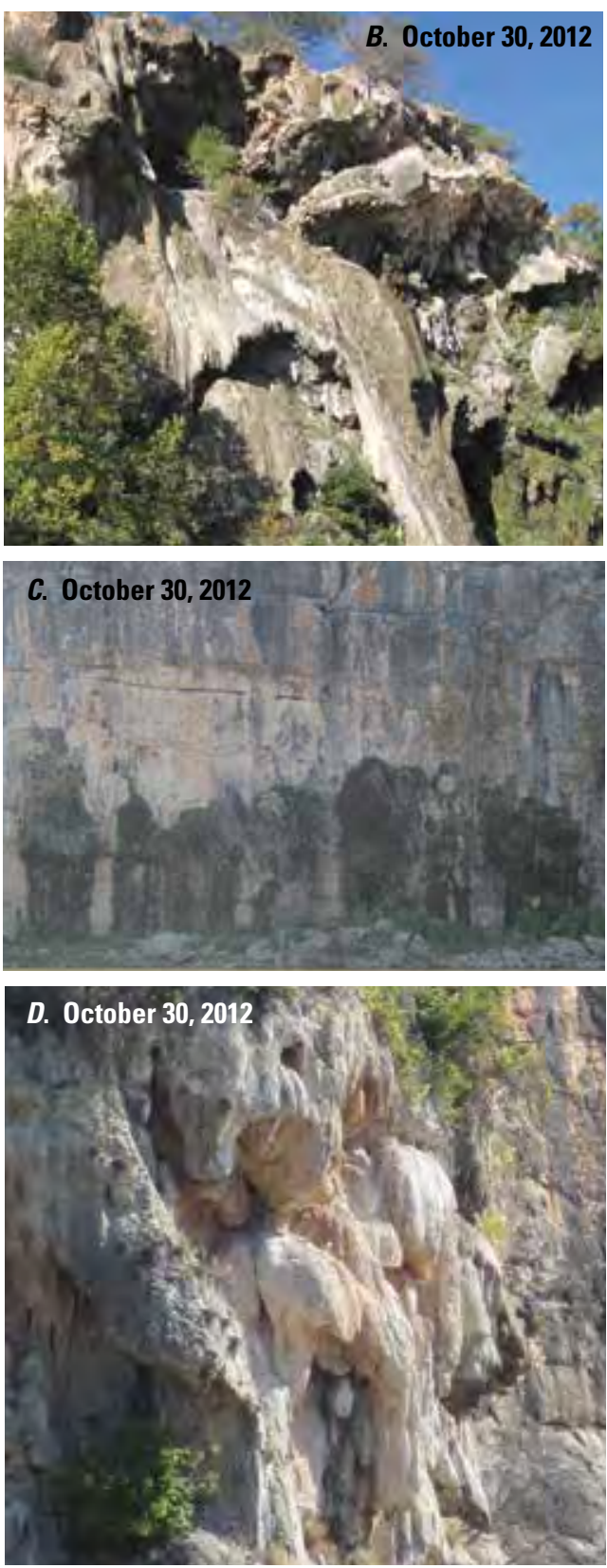

EXPLANATION

Hydrogeologic units

Alluvium

Ellenburger-San Saba

Confining units (Point Peak

Member and Morgan Creek Limestone)

Mid-Cambrian aquifer (Welge Sandstone and Lion Mountain Sandstone)

Approximate location of a combination of seeps or travertine deposits

NOTE: Photograph labels correspond to map locations.

Figure 8. Seeps, springs, and travertine deposits along the Colorado River in northwestern Burnet and southeastern San Saba Counties, Texas, and a map depicting photograph locations. $A$ and $C$, seeps; and $B$ and $D$, springs and associated travertine deposits. 

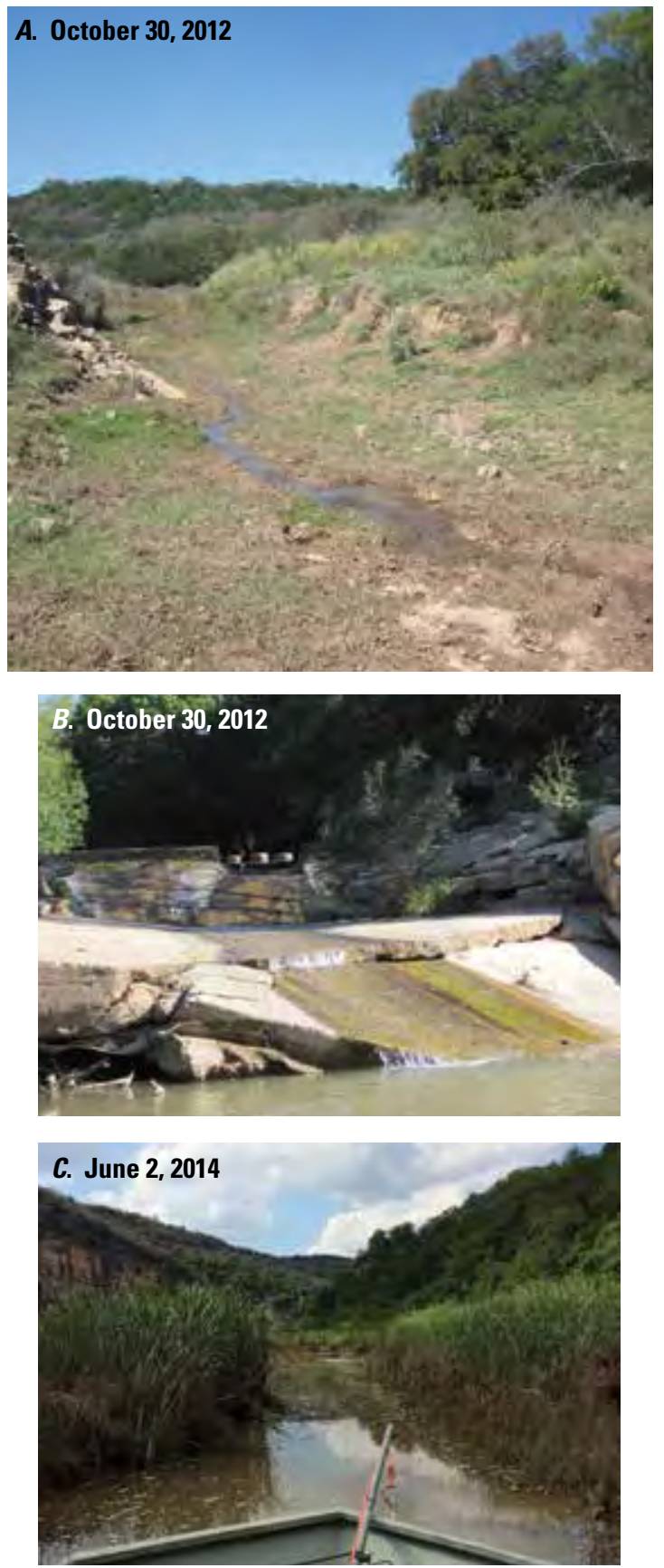

\section{EXPLANATION}

Hydrogeologic units

\section{Alluvium}

Ellenburger-San Saba

Confining units (Point Peak Member and Morgan Creek Limestone)

Mid-Cambrian aquifer (Welge Sandstone and Lion Mountain Sandstone)
T Fault-Ball and bar on downthrown block

A - Location where photograph was taken-Arrow indicates approximate orientation of photograph

DSB Most upstream streamflow or downstream measurement site-USB, upstream; DSB downstream
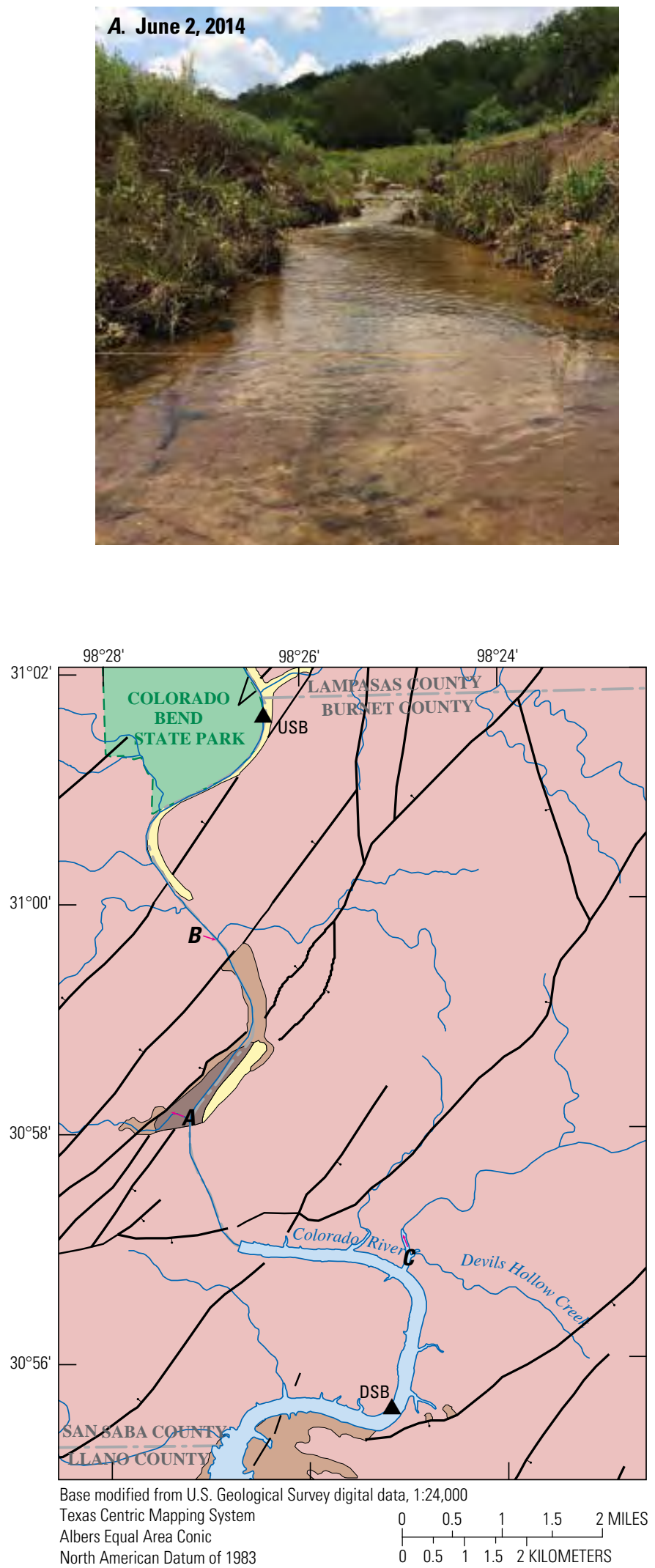

NOTES: Photograph labels correspond to map locations. Photographs at top of page

(October 30, 2012 and June 2, 2014) were taken at the same location, approximately 50 feet apart.

Figure 9. Tributary streams, which act as discharge points to the Colorado River in northwestern Burnet and southeastern San Saba Counties, Texas, and a map depicting photograph locations. $A$, Jim John Creek; $B$, Greenwood Creek; and $C$, Deer Creek. 
Table 2. Reaches evaluated for streamflow gains or losses on the Colorado River in northwestern Burnet and southeastern San Saba Counties, Texas, 2012-14.

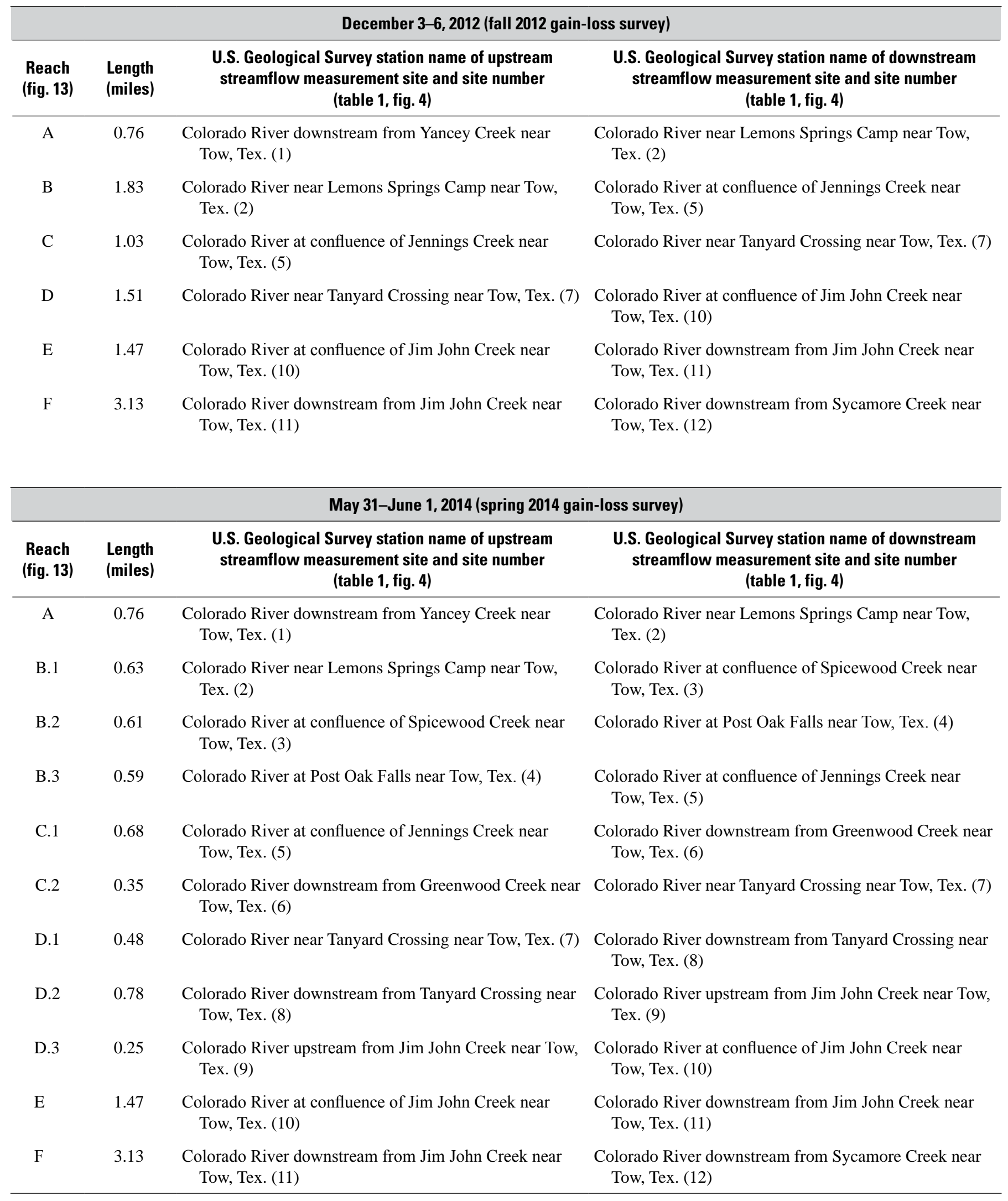


Discharge data from a Lower Colorado River Authority (LCRA) streamflow-gaging station (1925 Colorado River at Bend, Tex.; fig. 1) (Lower Colorado River Authority, 2015) and a USGS streamflow-gaging station $(08147000$ Colorado River near San Saba, Tex. [hereinafter Colorado River near San Saba]) were used to determine the optimal sampling times for the two gain-loss surveys. Based on long-term streamflow records (81 years) from Colorado River near San Saba, approximately $15.7 \mathrm{mi}$ upstream from the LCRA gage, the median streamflow in the Colorado River in that area during the October-December timeframe is slightly less than
$200 \mathrm{ft}^{3} / \mathrm{s}$ (U.S. Geological Survey, 2015). Uncharacteristically low streamflow (about $40 \mathrm{ft}^{3} / \mathrm{s}$ ) from October through December 2012 at Colorado River near San Saba provided an opportunity to quantify gains and losses during uncommon conditions (fig. 10). The intent was to return the following spring in May or June 2013 when it was anticipated that streamflow would likely range from about 300 to $500 \mathrm{ft}^{3} / \mathrm{s}$ (median streamflow based on 81 years of record is about $400 \mathrm{ft}^{3} / \mathrm{s}$ during May and June at the Colorado River near San Saba), providing an opportunity to target flow conditions for characterizations that were markedly different from those
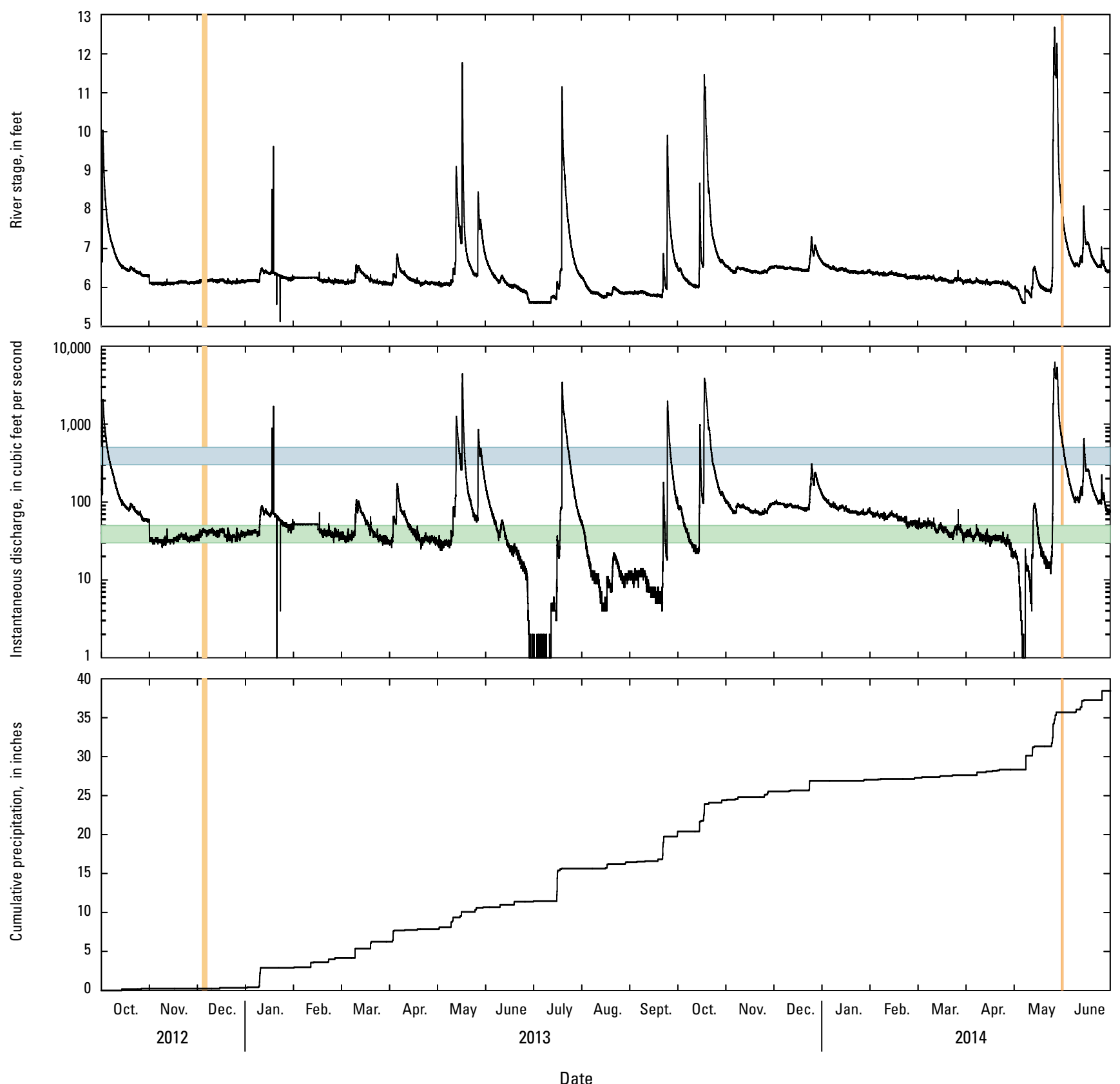

Figure 10. River stage, instantaneous discharge, and cumulative precipitation at Lower Colorado River Authority streamflow-gaging station 1925 Colorado River at Bend, Texas, October 1, 2012-June 30, 2014. 
measured during the fall 2012 gain-loss survey. A lack of appreciable winter rains, followed by severe drought during spring 2013, resulted in low streamflows unsuitable for the second set of synoptic discharge measurements. As a result of the unsuitable streamflow conditions in spring 2013, the second set of synoptic measurements was delayed until spring 2014.

The fall 2012 gain-loss survey represented a period of relatively stable base flow when appreciable rainfall and storm runoff were not occurring and had not occurred for at least the previous 2 weeks (figs. 10-11). The completion of gain-loss surveys during periods of relatively stable base flow helps minimize variations in streamflow conditions that might introduce errors into the estimation of gains and losses. Because unwadeable streamflow conditions were anticipated based on preliminary reconnaissance measurements made in October and November 2012, FlowTrackers attached to 8-foot (ft) wading rods were used to make discharge measurements from an inflatable raft as described in the "Methods" section. During the fall 2012 gain-loss survey, stream velocities were so low in some parts of the Colorado River that the FlowTrackers were not able to accurately measure the velocities. As a result, four of the predetermined measurement sites were moved downstream (sites 5, 7, and 11) or upstream (site 10) to more suitable locations. Measurement locations were presumed to be more suitable for accurate discharge measurements at locations where the Colorado River narrowed, typically (sites 5, 7, and 10) in conjunction with small tributaries to the Colorado River. Deltaic deposits from the tributaries created small peninsulas that extended into the Colorado River, resulting in narrowing of the Colorado River in these locations and relatively higher stream velocities compared to wider parts of the river. Because depths in the Colorado River remained relatively consistent throughout the lower part of the study area (downstream from Colorado Bend State Park), narrowing of the channel at these tributaries resulted in a slight increase in velocities at these locations as a consequence of the reduction in stream width.

The spring 2014 gain-loss survey was done following a large rain event on May 25 (2.46 inches), which was followed by additional rain on May 26 (0.54 inches) and May 27 (0.92 inches) (fig. 10). Because there were few opportunities with stable base flow in the desired flow range in the 18 months following the fall 2012 gain-loss survey (that is, appreciably larger flow compared to the low-flow conditions in the fall 2012 survey accompanied by an absence
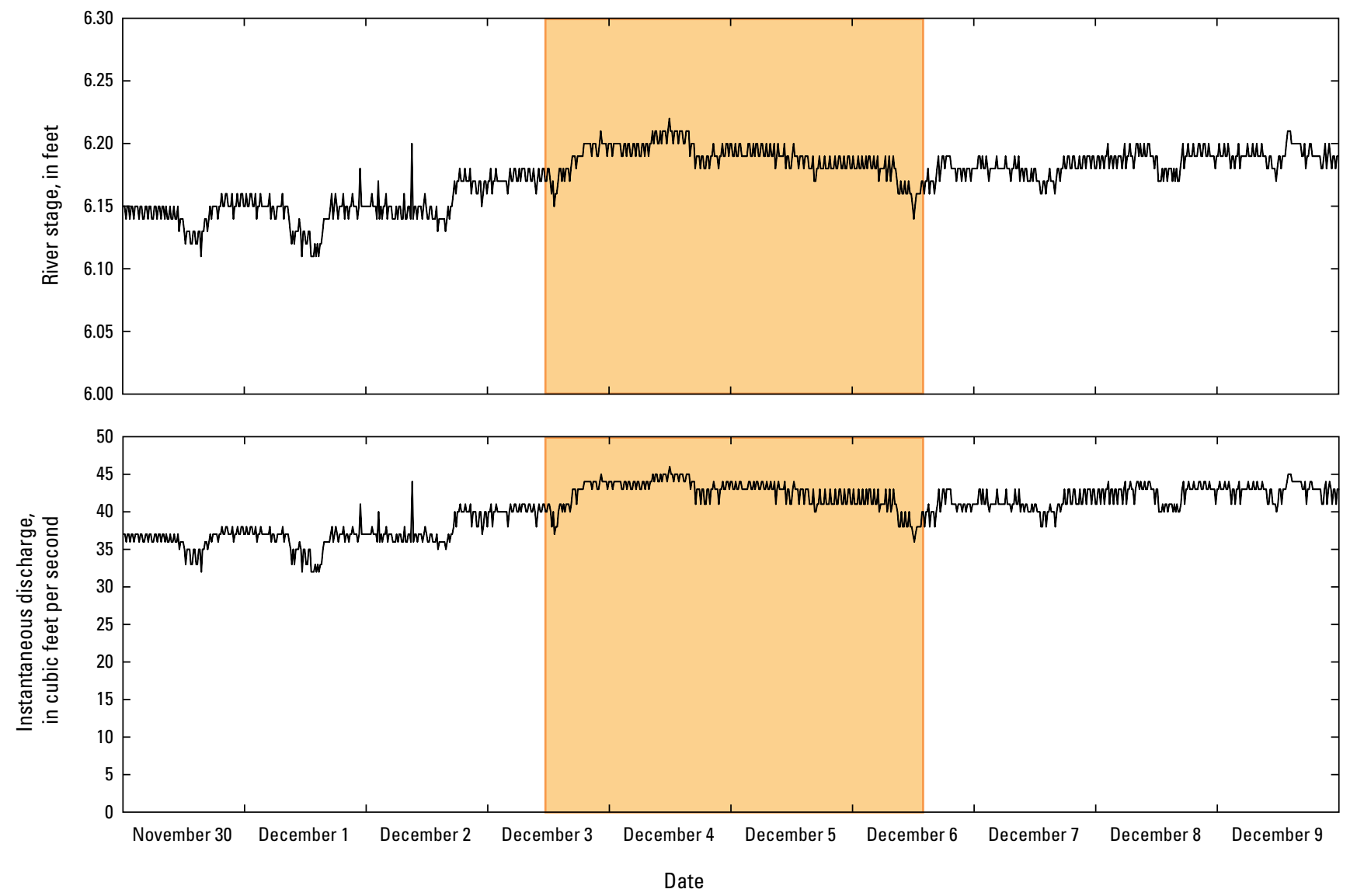

Figure 11. River stage and instantaneous discharge at Lower Colorado River Authority (LCRA) streamflow-gaging station 1925 Colorado River at Bend, Texas, November 30-December 9, 2012. 
of rain for at least 2 weeks) (fig. 10), the decision was made to complete the spring 2014 gain-loss survey during May 31-June 1 after streamflow began to recede and stabilize following the May 25-27 rainfall (figs. 10 and 12). Discharge measurement locations from the fall 2012 gain-loss survey were used again in the spring 2014 gain-loss survey for comparison purposes between the two gain-loss surveys, and additional sites were included in the spring 2014 gain-loss survey to provide supplementary data in support of gain-loss survey results. On the basis of previous measurement experience, the decision was made to use FlowTrackers attached to 4-ft wading rods to measure discharge at all wadeable sites, which turned out to be only the most upstream site on the Colorado River (USGS station 310134098262100 Colorado River downstream from Yancey Creek near Tow, Tex.; site 1 in table 1) and three tributary sites on streams that flow into the Colorado River (Jennings Creek, Jim John Creek, and Deer Creek) (table 3). All other discharge measurements were made by using an ADCP.

During the spring 2014 gain-loss survey, the accuracy of gain-loss determinations may have been affected by receding streamflow conditions. To eliminate or reduce the effects of receding streamflow conditions on gain-loss calculations, a discharge measurement at the upstream reach boundary should ideally be followed during receding streamflow conditions by a discharge measurement at the downstream boundary after a time interval that corresponds to the streamflow traveltime in the reach. Because the time interval between measurements at upstream and downstream reach boundaries did not correspond to the reach traveltime, measured streamflows were normalized to account for the difference between actual measurement times and estimated streamflow traveltime during the spring 2014 gain-loss survey. To normalize streamflows, the average velocity between sites as determined by the discharge measurements was used in conjunction with the distance between sites to define a traveltime for the water in a given reach. Once a traveltime was established for a reach, the average decrease in discharge per unit time between the two measurements at site 4 (Colorado River at Post Oak Falls near Tow, Tex.; hereinafter the Post Oak Falls site) was applied to the time allowed for streamflow in the Colorado River to travel downstream in order to compute a normalized discharge at each discharge measurement location downstream from the Post Oak Falls site. Because the discharge was known at the Post Oak Falls site (site 4; fig. 4, table 1) on both days that discharge measurements were made (last site measured on May 31, 2014, and first site measured on June 1, 2014), it was used as a starting point for the extrapolation of streamflows both upstream and downstream from that site.
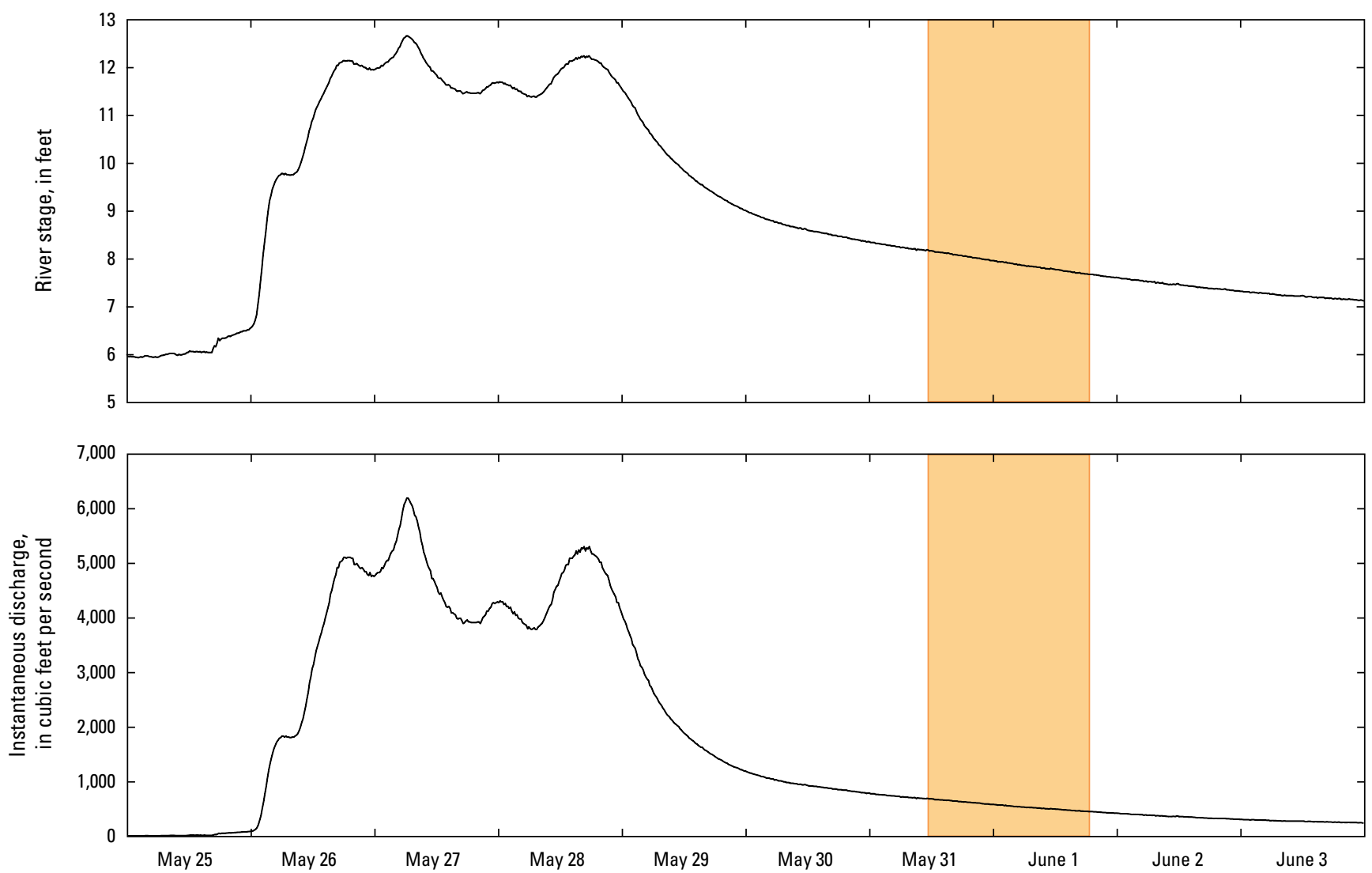

Figure 12. River stage and instantaneous discharge at Lower Colorado River Authority (LCRA) streamflow-gaging station 1925 Colorado River at Bend, Texas, May 25-June 3, 2014. 
Table 3. Description of tributary inflows to the Colorado River in northwestern Burnet and southeastern San Saba Counties, Texas, 2012-14.

[USGS, U.S. Geological Survey; $\mathrm{ft}^{3} \mathrm{~s}$, cubic feet per second; AM, abbreviated streamflow measurement with a hand-held acoustic Doppler velocimeter (FlowTracker); VE, visual estimate; FM, full streamflow measurement with a FlowTracker; SVE, surface velocity estimate; --, not measured]

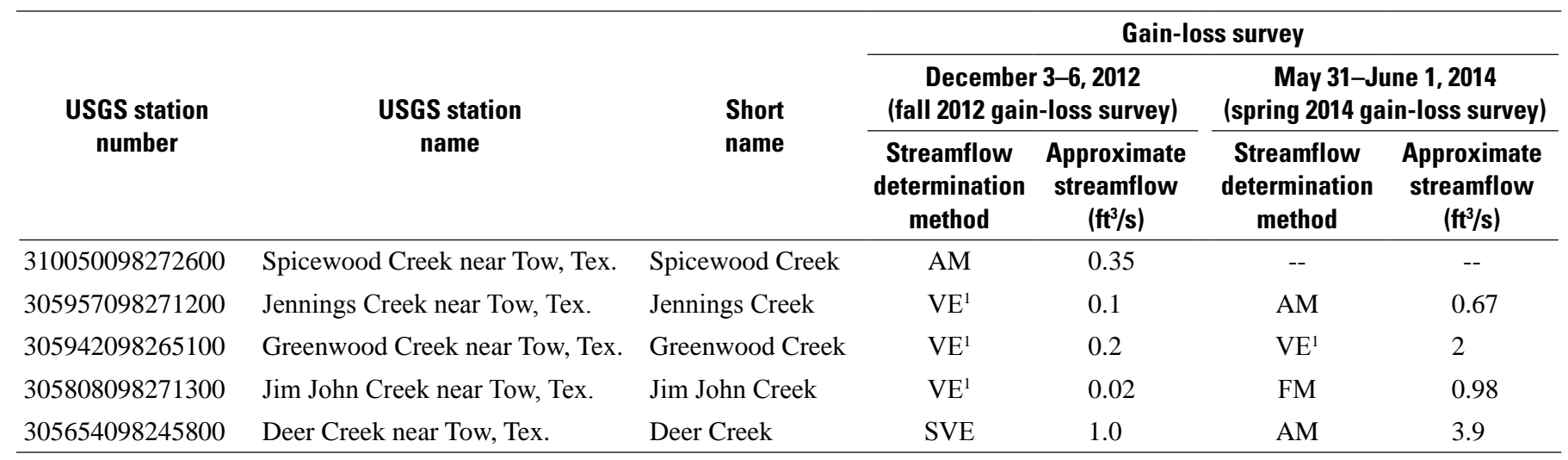

${ }^{1}$ Visual estimates were noncontact estimations of the upper limit of streamflow based on the hydrographer's experience measuring similar flows and were only made when (1) the flow could not be physically measured with the Flowtracker, and (2) it was readily apparent the flow in the tributary was trivial compared to the flow in the Colorado River and would not tangibly affect streamflow gain-loss calculations.

\section{Streamflow Gains and Losses}

Streamflow gains and losses are often in large part attributable to groundwater/surface-water interactions in the form of groundwater discharged to streams and groundwater recharged from streams (Winter and others, 1998). Groundwater/surface-water interactions are processes that typically cannot be measured directly because they usually cannot be observed. For this report, streamflow gains or losses within the study area were estimated by measuring the difference in streamflow at the upstream and downstream extent of each reach (table 4) while accounting for other sources of gains and losses. In addition to groundwater inflows, other sources of gains include tributary inflows, inflows from springs or seeps, and return flows. In addition to groundwater outflows, other sources of losses include stream diversions and evaporative losses. The difference between inflows and outflows, referred to as the streamflow gain or loss, $\mathrm{G}$, is estimated as

$$
G=Q_{D}-Q_{U}-I+D-R-S+E
$$

where

$Q_{D} \quad \begin{gathered}\text { is measured streamflow at the downstream } \\ \text { boundary of the reach, }\end{gathered}$
$Q_{U} \quad \begin{gathered}\text { is measured streamflow at the upstream } \\ \text { boundary of the reach, }\end{gathered}$
I is measured or estimated inflows from
tributaries,
D is diversions from the reach,
$R \quad$ is return flows to the reach,

$\mathrm{S}$ is inflows from springs or seeps, and

$\mathrm{E}$ is estimated evaporation losses.

(Units of all variables in cubic feet per second).

A positive value for $G$ indicates a gaining stream reach, whereas a negative value for $G$ indicates a losing stream reach. No diversions (D) or return flows $(R)$ were identified in the study area, so these contributions were not included in the streamflow gain or loss calculations. Schematic diagrams of the study area reaches, including discharge measurement sites and tributary inflows for the fall 2012 and spring 2014 gainloss surveys, are shown in figure 13.

Spring-flow contributions to streamflow often cannot be measured (Hem, 1985); even visible inflow from springs cannot always be accurately measured (Ockerman, 2002). Spring and seep contributions (S) to streamflow were not measured directly at any of the known springs in the study area. Contributions associated with springs that provide flow near site 4 (Post Oak Falls site) (photograph B in fig. 8) and springs associated with other travertine deposits near the southern end of the study area (photograph $D$ in fig. 8) could not be measured because the flow was divided between multiple release locations. Contributions associated with seeps (fig. 8A, C) also could not be measured and were considered negligible. As a result, spring contributions could not be included as a separate source in the streamflow gain or loss calculations.

By eliminating the terms $D, R$, and $S$ from equation 1 , equation 2 for $\mathrm{G}$ reduces to

$$
\mathrm{G}=\mathrm{Q}_{\mathrm{D}}-\mathrm{Q}_{U}-\mathrm{I}+\mathrm{E}
$$


Table 4. Summary of gain-loss determinations for reaches on the Colorado River in northwestern Burnet and southeastern San Saba Counties, Texas, 2012-14.

[ $\mathrm{ft}^{3} / \mathrm{s}$, cubic feet per second; positive value indicates gain or inflow entering the reach; negative value indicates loss or outflow leaving the reach. Green font indicates a verifiable streamflow gain that was larger than the measurement uncertainty associated with the discharge measurements made in this reach, and red font indicates a verifiable streamflow loss that was larger than the measurement uncertainty associated with the discharge measurements made in this reach; --, not measured]

\section{December 3-6, 2012 (fall 2012 gain-loss survey)}

\begin{tabular}{|c|c|c|c|c|c|c|c|c|}
\hline $\begin{array}{c}\text { Reach } \\
\text { (table 2; } \\
\text { fig. 13) }\end{array}$ & $\begin{array}{c}\text { Discharge } \\
\text { measured } \\
\text { at the } \\
\text { upstream site } \\
\left.\text { (ft }{ }^{3} / \mathrm{s}\right)\end{array}$ & $\begin{array}{c}\text { Discharge } \\
\text { measured } \\
\text { at the } \\
\text { downstream } \\
\text { site } \\
\left(\mathrm{ft}^{3} / \mathrm{s}\right)\end{array}$ & $\begin{array}{c}\text { Mean } \\
\text { streamflow } \\
\text { in reach } \\
\left(\mathrm{ft}^{3} / \mathbf{s}\right)\end{array}$ & $\begin{array}{c}\text { Measured } \\
\text { difference in } \\
\text { streamflow } \\
\text { within reach } \\
\left(\mathrm{ft}^{3} / \mathrm{s}\right)\end{array}$ & $\begin{array}{l}\text { Estimated } \\
\text { evaporation } \\
\text { loss within } \\
\text { reach }\end{array}$ & $\begin{array}{c}\text { Tributary } \\
\text { inflow from } \\
\text { creeks } \\
\text { within reach } \\
\left(\mathrm{ft}^{3} / \mathrm{s}\right)\end{array}$ & $\begin{array}{c}\text { Estimated } \\
\text { streamflow } \\
\text { gain or loss } \\
\text { within reach } \\
\left(\mathrm{ft}^{3} / \mathrm{s}\right)\end{array}$ & $\begin{array}{l}\text { with discharge } \\
\text { measurements } \\
\text { at the sites } \\
\text { defining } \\
\text { upstream and } \\
\text { downstream } \\
\text { extent of the } \\
\text { reach } \\
\left(\mathrm{ft}^{3} / \mathrm{s}\right)\end{array}$ \\
\hline A & 48.7 & 46.8 & 47.8 & -1.9 & 0.08 & 0.00 & -1.98 & 7.64 \\
\hline B & 46.8 & 56.2 & 51.5 & 9.4 & 0.23 & 0.35 & 9.52 & 9.36 \\
\hline $\mathrm{C}$ & 56.2 & 45.4 & 50.8 & -10.8 & 0.16 & 0.30 & -10.7 & 10.2 \\
\hline $\mathrm{D}$ & 45.4 & 29.6 & 37.5 & -15.8 & 0.30 & 0.02 & -16.1 & 7.5 \\
\hline $\mathrm{E}$ & 29.6 & 38.0 & 33.8 & 8.4 & 0.35 & 0.00 & 8.05 & 6.76 \\
\hline $\mathrm{F}$ & 38.0 & 45.2 & 41.6 & 7.2 & 0.87 & 1.0 & 7.33 & 8.32 \\
\hline
\end{tabular}

\begin{tabular}{|c|c|c|c|c|c|}
\hline $\begin{array}{c}\text { Reach } \\
\text { (table 2; } \\
\text { fig. 13) }\end{array}$ & $\begin{array}{c}\text { Discharge } \\
\text { measured } \\
\text { at the } \\
\text { upstream site } \\
\left(\mathrm{ft}^{3} / \mathrm{s}\right)\end{array}$ & $\begin{array}{c}\text { Discharge } \\
\text { measured } \\
\text { at the } \\
\text { downstream } \\
\text { site }\end{array}$ & $\begin{array}{c}\text { Mean } \\
\text { streamflow } \\
\text { in reach } \\
\left(\mathrm{ft}^{3} / \mathrm{s}\right)\end{array}$ & $\begin{array}{c}\text { Measured } \\
\text { difference in } \\
\text { streamflow } \\
\text { within reach } \\
\left(\mathrm{ft}^{3} / \mathrm{s}\right)\end{array}$ & $\begin{array}{c}\text { Estimated } \\
\text { evaporation } \\
\text { loss within } \\
\text { reach }\end{array}$ \\
\hline
\end{tabular}

Potential error associated with discharge Tributary Estimated measurements inflow from streamflow at the sites creeks gain or loss defining within reach within reach upstream and $\left(\mathrm{ft}^{3} / \mathrm{s}\right) \quad\left(\mathrm{ft}^{3} / \mathrm{s}\right)$

downstream extent of the reach $\left(\mathrm{ft}^{3} / \mathrm{s}\right)$

\begin{tabular}{|c|c|c|c|c|c|c|c|c|}
\hline A & 892 & 853 & 872 & -39 & 0.29 & 0 & -39.3 & 130 \\
\hline B. 1 & 853 & 835 & 844 & -18 & 0.22 & 0 & -18.2 & 83.6 \\
\hline B. 2 & 835 & 829 & 832 & -6 & 0.22 & 0 & -6.22 & 83.2 \\
\hline B. 3 & 679 & 687 & 683 & 8 & 0.23 & 0 & 7.77 & 67.4 \\
\hline C. 1 & 687 & 695 & 691 & 8 & 0.28 & 2.67 & 10.4 & 68.8 \\
\hline C. 2 & 695 & 701 & 698 & 6 & 0.15 & 0 & 5.85 & 70.5 \\
\hline D.1 & 701 & 702 & 702 & 1 & 0.23 & 0 & 0.77 & 70.4 \\
\hline D. 2 & 702 & 721 & 712 & 19 & 0.38 & 0 & 18.6 & 71.3 \\
\hline D.3 & 721 & 716 & 718 & -5 & 0.12 & 0.98 & -4.14 & 73.5 \\
\hline $\mathrm{E}$ & 716 & 754 & 735 & 38 & 0.75 & 0 & 37.2 & 76.3 \\
\hline F & 754 & 838 & 796 & 84 & 2.06 & 3.9 & 85.8 & 95.3 \\
\hline
\end{tabular}




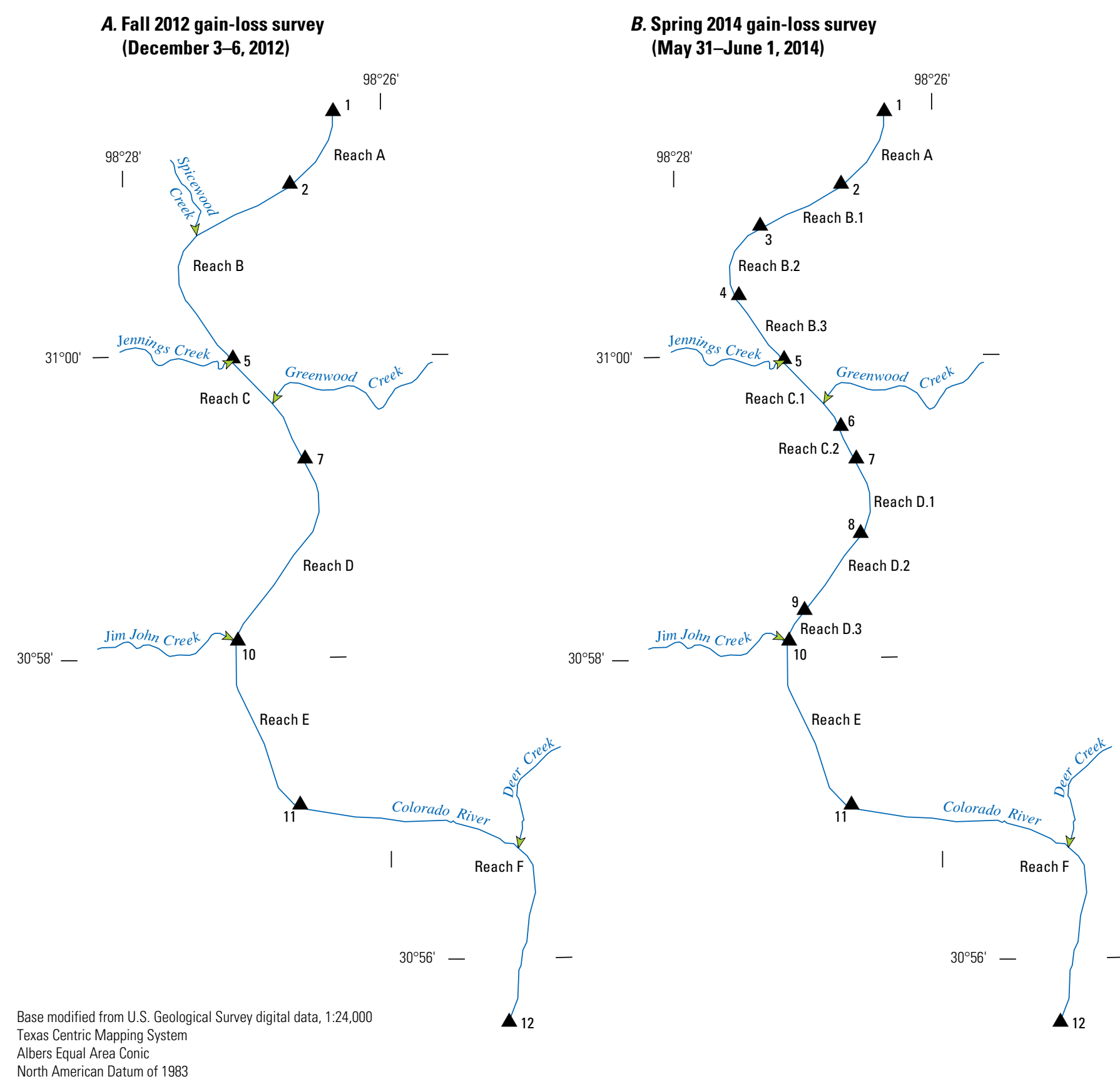

\section{EXPLANATION}

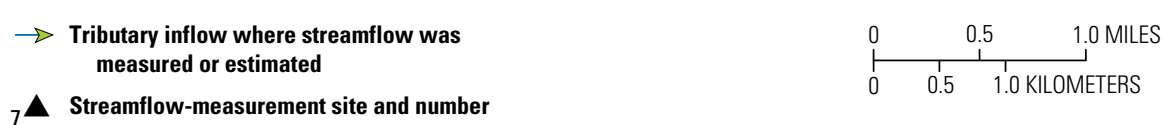

Figure 13. Study area reaches showing streamflow-measurement sites and tributary inflows along the Colorado River in northwestern Burnet and southeastern San Saba Counties, Texas. 
Discharge estimates and measurements for tributary inflows (I) were also made on tributaries to the Colorado River within the study area. In some cases (Spicewood Creek during the fall 2012 gain-loss survey and Jennings and Deer Creeks during the spring 2014 gain-loss survey; table 3), abbreviated discharge measurements were made by wading with a FlowTracker. Abbreviated discharge measurements were made in place of full discharge measurements because of narrow widths in these streams at the time of measurement. Although the use of abbreviated midsection discharge measurements in place of full midsection discharge measurements may result in a reduction in measurement accuracy, the magnitude of these tributary discharge measurement results relative to estimated streamflow gains or losses would make the loss of accuracy negligible. A full discharge measurement was made at the Jim John Creek near Tow, Tex., site during the spring 2014 gain-loss survey (table 3). In most other cases of tributary inflows to the Colorado River from small streams, a visual estimate of streamflow was made by an experienced hydrographer in lieu of measuring discharge, typically because depths or velocities were insufficient for making accurate velocity measurements with the FlowTracker. Visual estimates were noncontact estimations of the upper limit of streamflow based on the hydrographer's experience measuring similar flows and were only made when (1) the flow could not be physically measured with the FlowTracker, and (2) it was readily apparent the flow in the tributary was trivial compared to the flow in the Colorado River and would not tangibly affect streamflow gain-loss calculations. For example, Greenwood Creek was estimated as flowing at 0.2 and 2 $\mathrm{ft}^{3}$ /s during December 3-6, 2012, and May 31-June 1, 2014, respectively; the mean discharge in the Colorado River downstream from the confluence with Greenwood Creek during December 3-6, 2012, was 56.2 and $668 \mathrm{ft}^{3} / \mathrm{s}$ during December 3-6, 2012, and May 31-June 1, 2014, respectively. A surface velocity estimate of streamflow was made at one site (discharge measurement at the Deer Creek near Tow, Tex., site during the fall 2012 gain-loss survey) using equation 3 because it was determined to be the most appropriate streamflow estimation method:

$$
\mathrm{Q}=0.8\left(\mathrm{D} \times \mathrm{W} \times \mathrm{V}_{\mathrm{s}}\right)
$$

where
Q is estimated streamflow, in cubic feet per second;
D is average depth, in feet;
W is average width, in feet; and
$V_{s}$ is surface velocity, in feet per second.

Evaporation (E) within each reach was estimated by using mean lake evaporation data from two quadrangles (609 and 709) provided by the Texas Water Development Board (2014) because the study area extends across both quadrangles. The following equation was used to calculate the amount of streamflow lost to evaporation in each reach:

$$
\mathrm{E}_{\text {reach }}=\mathrm{Lf}(\mathrm{W} \times \mathrm{L}) \times \mathrm{E}_{\text {lake }}
$$

where

$$
\begin{aligned}
& E_{\text {reach }} \text { is the evaporation within each stream reach, in } \\
& \text { cubic feet per second; } \\
& \text { Lf is a dimensionless daylight factor (2.34 and } \\
& 1.72 \text { for the fall and spring gain-loss } \\
& \text { surveys, respectively); } \\
& \text { W is average of the stream widths measured at } \\
& \text { the upstream and downstream boundaries } \\
& \text { of the reach, in feet; } \\
& \mathrm{L} \quad \text { is reach length, in feet; and } \\
& \mathrm{E}_{\text {lake }} \text { is estimated lake evaporation, in feet per } \\
& \text { second. }
\end{aligned}
$$

Monthly lake evaporation rates for December 2012 were used for the fall 2012 gain-loss survey. Because 2014 evaporation data were not yet available, average monthly evaporation rates for the entire period of record (1955-2013) from both quadrangles during May and June were used to calculate evaporation losses from each stream reach during the spring 2014 gain-loss survey. The lake evaporation rate was applied to the surface area of each reach to compute an evaporation loss for the reach in cubic feet per second (apps. 1-2). Evaporative losses were assumed to occur only during the daytime hours, so the lake evaporation value applied to the reach was multiplied by a daylight factor (ratio of 24 hours to the hours of daylight) as described in Ockerman (2002, p. 7) to determine the evaporative rate during daytime hours. Data used in the calculation of evaporative loss estimates are listed in appendixes 1 and 2 for the fall 2012 and spring 2014 gainloss surveys, respectively.

For this report, a stream reach was classified as verifiably gaining or losing if the difference in streamflow between the upstream and downstream measuring sites exceeded the sum of the potential errors of the discharge measurements at the upstream and downstream measurement sites. Sauer and Meyer (1992, p. 2) describe how a measurement error rating (excellent, good, fair, or poor) is assigned to each discharge measurement by using a "quasi-quantitative method * * * based on a qualitative evaluation of several factors, such as cross section uniformity, velocity uniformity, stream bed conditions, and other factors that might, in the opinion of the streamgager, affect the accuracy of the measurement."

Additional factors that affect the accuracy of the measurement include the number of observations of width and depth, magnitude and homogeneity of streamflow velocity, and measurement statistics generated by the FlowTracker or ADCP data processing software. Discharge measurements were rated following the rating system developed by Sauer and Meyer (1992) to estimate measurement error of individual discharge measurements with excellent, good, and fair discharge measurements believed to be within 2, 5, and 8 percent of the actual streamflow, respectively. Discharge measurements rated as poor are believed to differ from actual flow by more than 8 percent; a value of 10 percent was used for the purpose 
of error calculations in this report. None of the discharge measurements made in either the fall 2012 or spring 2014 gain-loss surveys were rated as excellent. By multiplying the discharge measurement by the percent difference assigned to the measurement rating, a potential error for each measurement was determined. The potential errors associated with the upstream and downstream discharge measurements used to calculate gain-loss measurements for each reach were summed to obtain the potential composite error for comparison with the computed gain or loss (tables 4-5).

All of the streamflow discharges determined by wading the stream were an average of two measurements (table 1), with each measurement typically made by a different hydrographer using a FlowTracker. In all cases, the measurement rating was unchanged between consecutive discharge measurements at a site. A summary of gain-loss determinations for reaches along the Colorado River during both of the streamflow-measurement surveys is provided in table 4.

Of the 6 reaches assessed during the fall 2012 gainloss survey, 3 were gaining (reaches B, E, and F) and 3 (reaches A, C, and D) were losing, although only 4 of these 6 (reaches B through E) could be classified as verifiably gaining or losing streamflow because the potential error associated with the discharge measurements made at reaches $\mathrm{A}$ and $\mathrm{F}$ exceeded the difference in streamflow between the upstream and downstream measuring sites (fig. 14; table 4). The two reaches that were verifiably gaining streamflow were $\mathrm{B}$ and $\mathrm{E}$. The Colorado River in reach $\mathrm{B}$ crosses a combination of alluvium and Ellenburger-San Saba aquifer outcrop, whereas the Colorado River in reach $\mathrm{E}$ crosses the Ellenburger-San Saba aquifer outcrop exclusively (fig. 14; table 4). Streamflow gains in reaches B and E were likely a result of groundwater discharge flowing into the Colorado River from the Ellenburger-San Saba aquifer either directly or indirectly through the faults that cross each reach. Reaches $\mathrm{C}$ and D were verifiably losing streamflow in fall 2012. The Colorado River in reach C crosses several hydrogeologic features, including the Ellenburger-San Saba aquifer outcrop in the upper two-thirds of the reach, a fault, and aquifer confining units (Point Peak Member and Morgan Creek Limestone) in the lower third of the reach (fig. 14; table 4). Because the lower part of reach $\mathrm{C}$ crosses a confining unit, it is likely that most of the streamflow losses in this reach are either direct recharge to the Ellenburger-San Saba aquifer as water infiltrates into the subsurface from the streambed and provides recharge to the aquifer in the upper two-thirds of the reach, or indirect recharge as water moves downward through the fault that crosses the reach (fig. 14; table 4). Little is known about the precise nature of how the faults and groundwater system interact in the study area. Faults that cross stream channels can act either as barriers or pathways for groundwater flow (Grover and Bailey, 1919; Fenelon and others, 2012). The Colorado River in reach D crosses the same confining units as reach $\mathrm{C}$ in the upper 40 percent of the reach before transitioning to the Mid-Cambrian aquifer in the lower 60 percent of the reach (fig. 14; table 4). Because the upper part of reach D flows across a confining unit, it is more likely that most of the streamflow losses in this reach are associated with water infiltration into the subsurface from the streambed and recharge provided to the Mid-Cambrian aquifer.

During the spring 2014 gain-loss survey, most of the reaches (7 of 11) were gaining, although none of the reaches could be classified as verifiably gaining or losing because the potential error (table 4) associated with the discharge measurements made in each of the 11 reaches exceeded the difference in streamflow between the upstream and downstream measuring sites (table 4). Therefore, reaches were combined in an attempt to consolidate streamflow gains or losses while keeping potential error relatively constant (fig. 15; table 5). In order to facilitate direct comparisons between the results of the fall 2012 and spring 2014 gainloss surveys, the 11 reaches established in the spring 2014 gain-loss survey were initially combined to match the extents of the 6 reaches (A, B, C, D, E, and F) from the fall 2012 gain-loss survey (for example, spring 2014 reaches B.1, B.2, B.3, were combined into a reach B) (table 2). After combining the reaches in this manner, the potential error associated with the upstream and downstream flow measurements within each reach still exceeded the estimated streamflow gains or losses within each reach, so none of the reaches could be classified as verifiably gaining or losing. Thus, reaches were combined a second time to reduce the number from 6 to 3 (referred to as reaches $\mathrm{AB}, \mathrm{BD}, \mathrm{EF}$ ) in an attempt to consolidate gains and losses and group reaches together when they crossed the same hydrogeologic units (fig. 15; table 5). An estimated loss of $63.7 \mathrm{ft}^{3} / \mathrm{s}$ was measured in reach $\mathrm{AB}$ (a combination of reaches A, B.1, and B.2) that flows across a combination of alluvium and the Ellenburger-San Saba aquifer outcrop, which was much smaller than the potential measurement error of $129 \mathrm{ft}^{3} / \mathrm{s}$, resulting in an unverifiable loss. Reach BD flows across each of the different hydrogeologic units represented in the study area (fig. 15) and is a combination of 6 of the 11 reaches (B.3, C.1, C.2, D.1, D.2, and D.3) that were examined initially in the spring 2014 gain-loss survey (fig. 15; table 5). Of the 6 reaches that combined to make up reach $\mathrm{BD}, 5$ were unverifiably gaining, whereas the sixth (D.3) was unverifiably losing. An estimated gain of $39.3 \mathrm{ft}^{3} / \mathrm{s}$ was measured for reach $\mathrm{BD}$, which was unverifiable because it was smaller than the potential error of $71.5 \mathrm{ft}^{3} / \mathrm{s}$. A verifiable streamflow gain of $123 \mathrm{ft}^{3} / \mathrm{s}$ was measured in reach EF, which flows exclusively across the Ellenburger-San Saba aquifer; the estimated gain in streamflow exceeded the potential error of $93.9 \mathrm{ft}^{3} / \mathrm{s}$ for this reach. This means that the EllenburgerSan Saba aquifer is losing in this part of the study area at flow conditions observed during the spring 2014 gain-loss survey. 
Table 5. Summary of gain-loss determinations during the spring 2014 gain-loss survey for reaches on the Colorado River in northwestern Burnet and southeastern San Saba Counties, Texas, 2012-14.

$\left[\mathrm{ft}^{3} / \mathrm{s}\right.$, cubic feet per second; positive value indicates gain or inflow entering the reach; negative value indicates loss or outflow leaving the reach. Green font indicates a streamflow gain that exceeded the measurement uncertainty for this reach; --, not measured]

\begin{tabular}{|c|c|c|c|c|c|c|c|c|c|c|c|}
\hline $\begin{array}{c}\text { Reach } \\
\text { (table 2; } \\
\text { fig. 13) }\end{array}$ & $\begin{array}{c}\text { Discharge } \\
\text { measured at the } \\
\text { upstream site } \\
\left(\mathrm{ft}^{3} / \mathrm{s}\right)\end{array}$ & \multicolumn{2}{|c|}{$\begin{array}{c}\text { measured at } \\
\text { the } \\
\text { downstream } \\
\text { site } \\
\left(\mathrm{ft}^{3} / \mathrm{s}\right) \\
\end{array}$} & $\begin{array}{c}\text { Mean } \\
\text { adjusted } \\
\text { streamflow } \\
\text { in reach }\end{array}$ & $\begin{array}{l}\text { Measured } \\
\text { difference in } \\
\text { adjusted } \\
\text { streamflow } \\
\text { within reach }\end{array}$ & $\begin{array}{c}\text { Estimated } \\
\text { evaporation } \\
\text { loss } \\
\text { within } \\
\text { reach }\end{array}$ & $\begin{array}{l}\text { Tributary } \\
\text { inflow from } \\
\text { creeks } \\
\text { within } \\
\text { reach }\end{array}$ & $\begin{array}{c}\text { Estimated } \\
\text { streamflow } \\
\text { gain or loss } \\
\text { within } \\
\text { reach }\end{array}$ & $\begin{array}{c}\text { Potential error } \\
\text { from streamflow } \\
\text { measurement at } \\
\text { upstream site } \\
\left(\mathrm{ft}^{3} / \mathrm{s}\right)\end{array}$ & $\begin{array}{c}\text { Potential error } \\
\text { from streamflow } \\
\text { measurement at } \\
\text { downstream site } \\
\left(\mathrm{ft}^{3} / \mathrm{s}\right)\end{array}$ & $\begin{array}{c}\text { Sum of potential } \\
\text { error from streamflow } \\
\text { measurements at } \\
\text { upstream and } \\
\text { downstream sites } \\
\left(\mathrm{ft}^{3} / \mathrm{s}\right) \\
\end{array}$ \\
\hline A & 892 & \multicolumn{2}{|c|}{853} & 872 & -39 & 0.29 & 0 & -39.3 & 87.7 & 41.8 & 130 \\
\hline B.1 & 853 & \multicolumn{2}{|c|}{835} & 844 & -18 & 0.22 & 0 & -18.2 & 41.8 & 41.8 & 83.6 \\
\hline B. 2 & 835 & \multicolumn{2}{|c|}{829} & 832 & -6 & 0.22 & 0 & -6.2 & 41.8 & ${ }^{1} 41.4$ & 83.2 \\
\hline B.3 & 679 & \multicolumn{2}{|c|}{687} & 683 & 8 & 0.23 & 0 & 7.8 & 234.0 & 33.4 & 67.4 \\
\hline C.1 & 687 & \multicolumn{2}{|c|}{695} & 691 & 8 & 0.28 & 2.67 & 10.4 & 33.4 & 35.4 & 68.8 \\
\hline C. 2 & 695 & \multicolumn{2}{|c|}{701} & 698 & 6 & 0.15 & 0 & 5.8 & 35.4 & 35.1 & 70.5 \\
\hline D.1 & 701 & \multicolumn{2}{|c|}{702} & 702 & 1 & 0.23 & 0 & 0.8 & 35.1 & 35.3 & 70.4 \\
\hline D. 2 & 702 & \multicolumn{2}{|c|}{721} & 712 & 19 & 0.38 & 0 & 18.6 & 35.3 & 36.0 & 71.3 \\
\hline D.3 & 721 & \multicolumn{2}{|c|}{716} & 718 & -5 & 0.12 & 0.98 & -4.1 & 36.0 & 37.5 & 73.5 \\
\hline $\mathrm{E}$ & 716 & \multicolumn{2}{|c|}{754} & 735 & 38 & 0.75 & 0 & 37.3 & 37.5 & 38.8 & 76.3 \\
\hline $\mathrm{F}$ & 754 & \multicolumn{2}{|c|}{838} & 796 & 84 & 2.06 & 3.9 & 85.8 & 38.8 & 56.5 & 95.3 \\
\hline \multicolumn{3}{|c|}{$\begin{array}{l}\text { Selected reaches combined by } \\
\text { using the most upstream and } \\
\text { downstream measurement sites } \\
\text { from the first gain-loss survey } \\
\text { (see table } 2 \text { for description } \\
\text { and fig. } 14 \text { for location) }\end{array}$} & \multicolumn{2}{|c|}{$\begin{array}{l}\text { Estimated streamflow } \\
\text { gain or loss within } \\
\text { a reach defined by } \\
\text { streamflow-measure- } \\
\text { ment sites from the first } \\
\text { gain-loss survey }\end{array}$} & $\begin{array}{l}\text { Potential error } \\
\text { from stream- } \\
\text { flow mea- } \\
\text { surement at } \\
\text { upstream site } \\
\left(\mathrm{ft}^{3} / \mathrm{s}\right)\end{array}$ & $\begin{array}{c}\text { Potential } \\
\text { error from } \\
\text { streamflow } \\
\text { measurement } \\
\text { at downstream } \\
\text { site } \\
\left(\mathrm{ft}^{3} / \mathrm{s}\right)\end{array}$ & \multicolumn{2}{|c|}{$\begin{array}{l}\text { Sum of potential error } \\
\text { from streamflow } \\
\text { measurements at } \\
\text { upstream and down- } \\
\text { stream sites of reaches } \\
\text { A, B, C, D, E, and F } \\
\left(\mathrm{ft}^{3} / \mathrm{s}\right)\end{array}$} & $\begin{array}{l}\text { Reaches further } \\
\text { grouped to mini- } \\
\text { mize potential } \\
\text { measurement } \\
\text { errors } \\
\text { (see fig. } 14 \text { for } \\
\text { location) }\end{array}$ & $\begin{array}{l}\text { Estimated } \\
\text { streamflow gain } \\
\text { or loss within } \\
\text { reach grouped } \\
\text { to minimize po- d } \\
\text { tential measur- } \\
\text { ment errors }\end{array}$ & $\begin{array}{l}\text { Potential error associated } \\
\text { with discharge measure- } \\
\text { ments from the sites } \\
\text { defining upstream and } \\
\text { downstream extent of the } \\
\text { grouped reaches } \\
\text { (reach AB, BD, and EF) }\end{array}$ \\
\hline \multicolumn{2}{|r|}{ A } & \multicolumn{3}{|r|}{-39.3} & 87.7 & 41.8 & \multicolumn{2}{|c|}{130} & \multirow[t]{2}{*}{$\mathrm{AB}$} & -63.7 & \multirow[t]{2}{*}{129} \\
\hline \multicolumn{2}{|r|}{$\mathrm{B}^{4}$} & \multicolumn{3}{|r|}{-16.7} & 41.8 & 33.4 & \multicolumn{2}{|c|}{75.2} & & & \\
\hline \multicolumn{2}{|r|}{$C^{5}$} & \multicolumn{3}{|r|}{16.2} & 33.4 & 35.1 & \multicolumn{2}{|c|}{68.5} & \multirow[t]{2}{*}{$\mathrm{BD}$} & 39.3 & 71.5 \\
\hline \multicolumn{2}{|r|}{$\mathrm{D}^{6}$} & \multicolumn{3}{|r|}{15.2} & 35.1 & 37.5 & \multicolumn{2}{|c|}{72.6} & & & \\
\hline & $\mathrm{E}$ & & & 37.3 & 37.5 & 38.8 & & 76.3 & $\mathrm{EF}$ & 123 & 94.0 \\
\hline & $\mathrm{F}$ & & & 85.8 & 38.8 & 56.5 & & 95.3 & & & \\
\hline
\end{tabular}

${ }^{1}$ Based on streamflow measurement made on May 31, 2014.

${ }^{2}$ Based on streamflow measurement made on June 1, 2014.

${ }^{3}$ Reaches $\mathrm{A}-\mathrm{F}$ were combined into upstream, middle, and downstream reaches (reach $\mathrm{AB}$, reach $\mathrm{BD}$, and reach $\mathrm{EF}$ ) in an attempt to consolidate gains and losses as well as group reaches within the same hydrogeologic units.

${ }^{4}$ Reaches B.1, B.2, and B.3 combined.

${ }^{5}$ Reaches C.1 and C. 2 combined.

${ }^{6}$ Reaches D.1, D.2, and D.3 combined. 


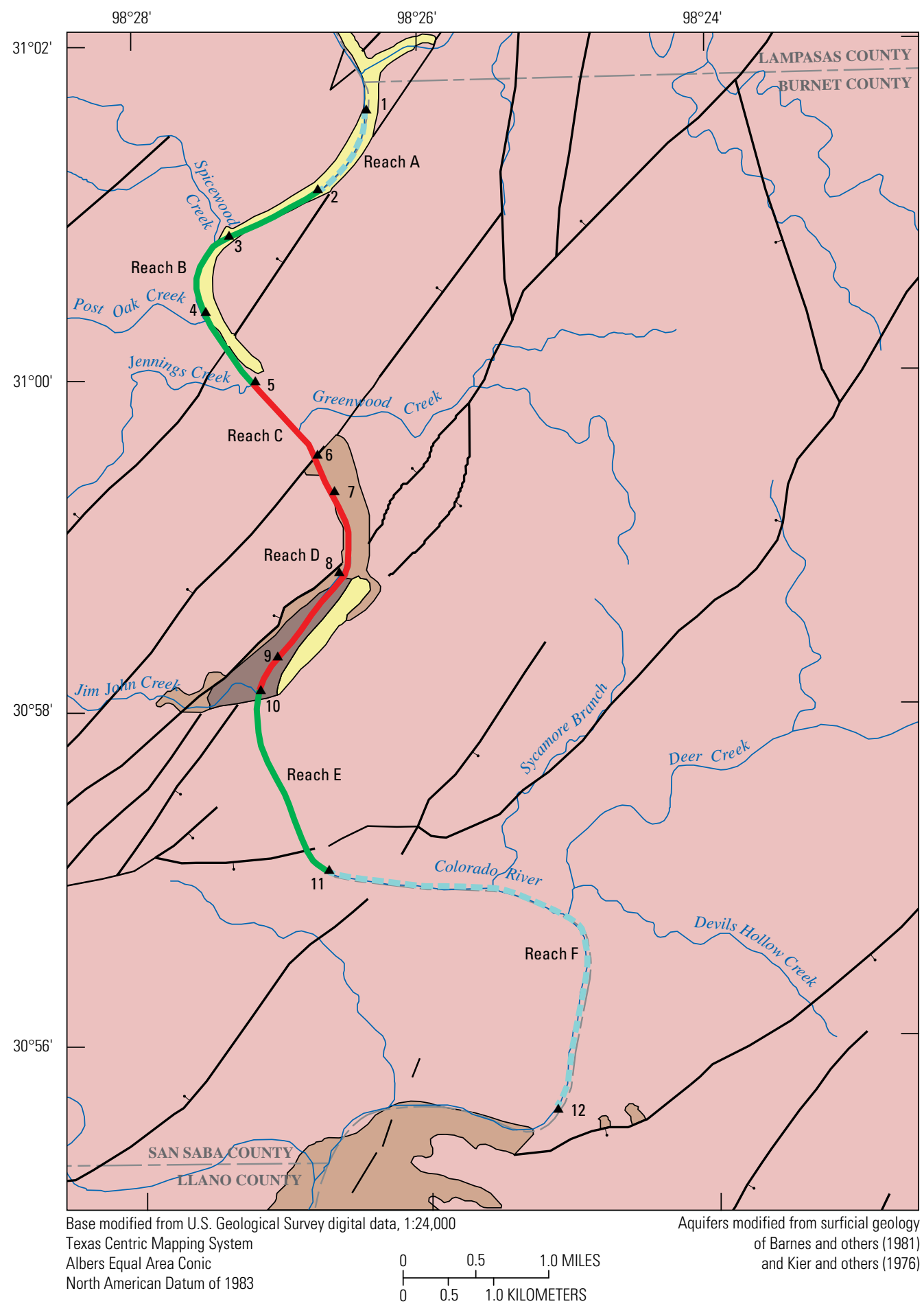

orth American Datum of 1983

\section{EXPLANATION}

Hydrogeologic units

Alluvium

Ellenburger-San Saba

Confining units (Point Peak Member and Morgan Creek Limestone)

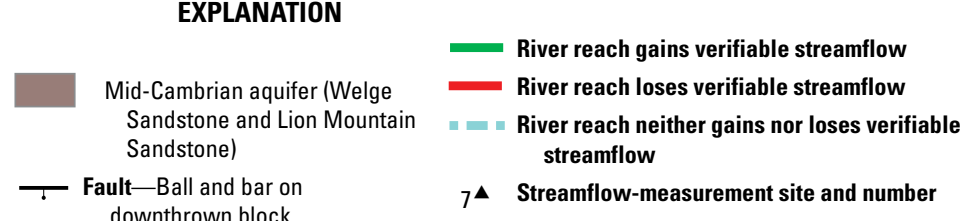
downthrown block
$7^{\Delta}$ Streamflow-measurement site and number

Figure 14. Reaches that were verifiably gaining or losing or unverifiably gaining or losing during the fall 2012 gain-loss survey in northwestern Burnet and southeastern San Saba Counties, Texas. 


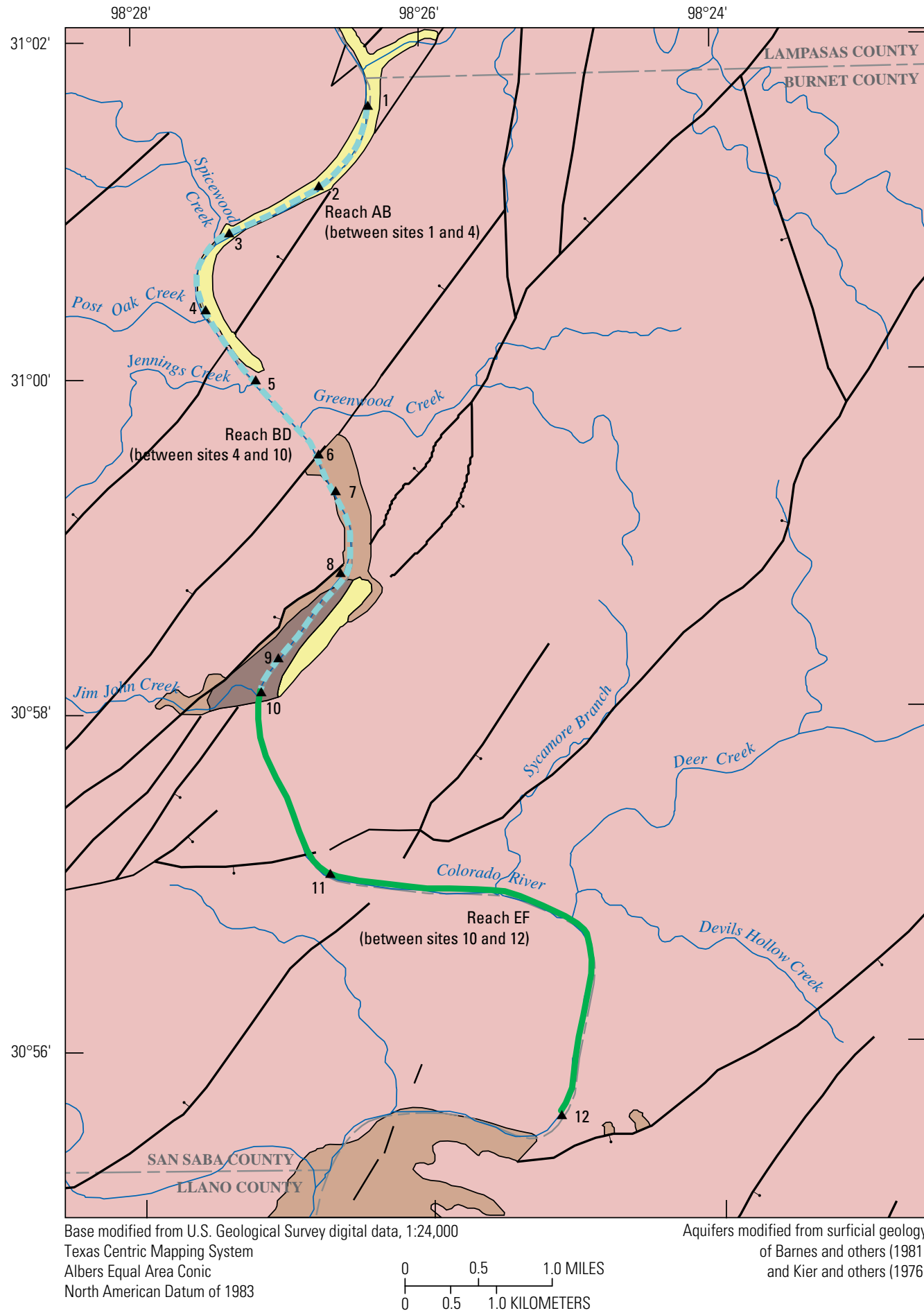

\section{Hydrogeologic units}

Alluvium

Ellenburger-San Saba

Confining units (Point Peak Member and Morgan Creek Limestone)

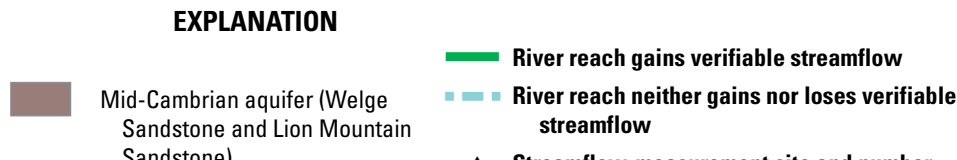

${ }_{7} \Delta$ Streamflow-measurement site and number

Figure 15. Reaches that were verifiably gaining or losing or unverifiably gaining or losing during the spring 2014 gain-loss survey in northwestern Burnet and southeastern San Saba Counties, Texas. 


\section{Summary}

In October 2012, the U.S. Geological Survey (USGS), in cooperation with the Central Texas Groundwater Conservation District (CTGCD), began a gain-loss study of streamflow in the Colorado River in northwestern Burnet and southeastern San Saba Counties, Texas. This report presents the results of the study to determine if different reaches of the Colorado River in northwestern Burnet and southeastern San Saba Counties are gaining or losing streamflow, where the gains and losses have occurred and in what quantities, and whether the gains and losses can be attributed to interaction of groundwater and surface water between the Ellenburger-San Saba aquifer and the Colorado River.

Two sets of synoptic discharge measurements were made under different flow conditions. In the first gain-loss survey during December 3-December 6, 2012 (hereinafter the fall 2012 gain-loss survey), discharge measurements were made at low-flow conditions ranging from about 30 to 60 cubic feet per second $\left(\mathrm{ft}^{3} / \mathrm{s}\right)$ at seven locations along the Colorado River. In the second gain-loss survey during May 31-June 1 (hereinafter the spring 2014 gain-loss survey), discharge measurements were made at high-flow conditions ranging from about 660 to $900 \mathrm{ft}^{3} / \mathrm{s}$ at 12 locations along the Colorado River. Discharge measurement locations were selected for the gain-loss surveys based on several criteria including the locations of hydrogeologic unit contacts, faults, seeps, springs, travertine deposits, and tributary inflows.

During the fall 2012 gain-loss survey, verifiable gains or losses of streamflow were identified in 4 of 6 reaches (the difference in measured discharge between the upstream and downstream boundaries of the reach was larger than the sum of potential errors associated with the two discharge measurements). The two reaches with a verifiable gain in streamflow cross areas where the Ellenburger-San Saba aquifer crops out. The more upstream of the two reaches with verifiable losses crosses a small part of the Ellenburger-San Saba aquifer outcrop and confining units (Point Peak Member and Morgan Creek Limestone); it is possible streamflow losses in this reach are in the form of recharge to the Ellenburger-San Saba aquifer; little streamflow is likely lost to the underlying formations in the downstream part of the reach, which consists of relatively impermeable aquifer confining units exposed at land surface. The more downstream of the two reaches where a verifiable loss of streamflow was measured also flows across relatively impermeable confining units before crossing the Mid-Cambrian aquifer outcrop in the lower part of the reach; most of the streamflow losses in this reach were likely a result of water infiltration into the subsurface from the streambed and recharge provided to the relatively permeable MidCambrian aquifer.

During the spring 2014 gain-loss survey, most of the reaches (7 of 11) were gaining although none of the reaches could be classified as verifiably gaining or losing because the potential error associated with the flow measurements made at each of the 11 reaches exceeded the difference in streamflow between the upstream and downstream measuring sites. The 11 reaches were combined into upstream, middle, and downstream reaches (reach $\mathrm{AB}$, reach $\mathrm{BD}$, and reach $\mathrm{EF}$ ) in an attempt to consolidate gains and losses as well as group reaches within the same hydrogeologic units. An unverifiable loss in streamflow of $63.7 \mathrm{ft}^{3} / \mathrm{s}$ was measured in the upstream reach $\mathrm{AB}$, which flows across a combination of alluvium and the Ellenburger-San Saba aquifer outcrop. The loss in reach $\mathrm{AB}$ was considered unverifiable because it was smaller than the potential measurement error of $129 \mathrm{ft}^{3} / \mathrm{s}$ determined from discharge measurements used to estimate the loss. An estimated gain of $39.3 \mathrm{ft}^{3} / \mathrm{s}$ was measured in middle reach BD that flows across each of the different hydrogeologic units represented in the study area; this estimated gain was smaller than the potential error of $71.5 \mathrm{ft}^{3} / \mathrm{s}$, so it was also considered unverifiable. The reach farthest downstream in the study area (reach EF) flows exclusively across the Ellenburger-San Saba aquifer. A streamflow gain of $123 \mathrm{ft}^{3} / \mathrm{s}$ was measured in reach $\mathrm{EF}$, which was larger than the potential error of $93.9 \mathrm{ft}^{3} / \mathrm{s}$ for this reach. This means that groundwater from the EllenburgerSan Saba aquifer is likely contributing to streamflow in this part of the study area at the flow conditions observed during the spring 2014 gain-loss survey.

\section{References}

Barlow, P.M., and Leake, S.A., 2012, Streamflow depletion by wells-Understanding and managing the effects of groundwater pumping on streamflow: U.S. Geological Survey Circular 1376, 84 p. [Also available at http://pubs. usgs.gov/circ/1376/.]

Barnes, V.E., Shell Oil Co., Boyer, R.E., Clabaugh, S.E., and Baker, E.T., 1981, Geologic atlas of Texas, Llano sheet: The University of Texas at Austin, Bureau of Economic Geology, accessed April 22, 2015, at http://www.twdb.texas. gov/groundwater/aquifer/GAT/llano.htm.

Berehe, A.K., 2005, Updated evaluation for the Williamson, Burnet and northern Travis Counties priority groundwater management study area: Texas Commission on Environmental Quality, Priority Groundwater Management Area File Report, 134 p.

Fenelon, J.M., Sweetkind, D.S., Elliott, P.E., and Laczniak, R.J., 2012, Conceptualization of the predevelopment groundwater flow system and transient water-level responses in Yucca Flat, Nevada National Security Site, Nevada: U.S. Geological Survey Scientific Investigations Report 2012-5196, 61 p.

Grover, N.C., and Bailey, C.T., 1919, Surface water supply of Hawaii_-July 1, 1917 to June 30, 1918: U.S. Geological Survey Water Supply Paper 485, 169 p., accessed April 23, 2015, at http://pubs.usgs.gov/wsp/0485/report.pdf. 
Healy, R.W., Winter, T.C., LaBaugh, J.W., and Franke, O.L., 2007, Water budgets-Foundations for effective waterresources and environmental management: U.S. Geological Survey Circular 1308, 90 p.

Hem, J.D., 1985, Study and interpretation of the chemical characteristics of natural water (3d ed.): U.S. Geological Survey Water-Supply Paper 2254, 263 p. (Reprinted 1992.)

Kier, R.S., Brown, L.F., Harwood, P., Jr., and Goodson, J.L., 1976, Geologic atlas of Texas, Brownwood sheet: The University of Texas at Austin, Bureau of Economic Geology, accessed April 22, 2015, at http://www.twdb.texas. gov/groundwater/aquifer/GAT/brownwood.htm.

Lower Colorado River Authority, 2015, LCRA hydrologic data: Accessed on April 23, 2015, at http://hydromet.lcra. org/full.aspx.

Maurer, D.K., Berger, D.L., Tumbusch, M.L., and Johnson, M.J., 2006, Rates of evapotranspiration, recharge from precipitation beneath selected areas of native vegetation, and streamflow gain and loss in Carson Valley, Douglas County, Nevada, and Alpine County, California: U.S. Geological Survey Scientific Investigations Report 2005 5288, 70 p. [Also available at http://pubs.water.usgs.gov/ sir2005-5288.]

Mueller, D.S., Wagner, C.R., Rehmel, M.S., Oberg, K.A., and Rainville, Francois, 2013, Measuring discharge with acoustic Doppler current profilers from a moving boat (ver. 2.0, December 2013): U.S. Geological Survey Techniques and Methods, book 3, chap. A22, 95 p., accessed June 15, 2015, at http://dx.doi.org/10.3133/tm3A22.

Oberg, K.A., Morlock, S.E., and Caldwell, W.S., 2005, Quality-assurance plan for discharge measurements using acoustic Doppler current profilers: U.S. Geological Survey Scientific Investigations Report 2005-5183, 35 p.

Ockerman, D.J., 2002, Gain-loss study of lower San Pedro Creek and the San Antonio River, San Antonio, Texas, May-October 1999: U.S. Geological Survey Open-File Report 2002-023, 15 p.

Pinder, G.F., and Celia, M.A., 2006, Groundwater-surfacewater interaction, in Subsurface Hydrology: Hoboken, N.J., John Wiley and Sons, Inc., p. 343-365, doi: 10.1002/0470044209.ch9.
Preston, R.D., Pavilcek, D.J., Bluntzer, R.L., and Derton, John, 1996, The Paleozoic and related aquifers of central Texas: Texas Water Development Board Report 346, 95 p., accessed June 17, 2015, at https://www.twdb.texas.gov/ publications/reports/numbered_reports/doc/R346/R346.pdf.

Rantz, S.E., and others, 1982, Measurement and computation of streamflow-Volumes 1 and 2: U.S. Geological Survey Water-Supply Paper 2175, 631 p.

Sauer, V.B., and Meyer, R.W., 1992, Determination of error in individual discharge measurements: U.S. Geological Survey Open-File Report 92-144, 21 p. [Also available online at http://pubs.usgs.gov/of/1992/ofr92-144/.]

SonTek, 2013, FlowTracker handheld acoustic Doppler velocimeter: Accessed February 6, 2013, at http://www. sontek.com/flowtracker.php.

Teledyne RD Instruments, 2007, WinRiver II user’s guide: San Diego, Calif., Teledyne RD Instruments, P/N 957-6231-00, $166 \mathrm{p}$.

Texas Water Development Board, 2014, Precipitation and lake evaporation: Accessed on December 19, 2014, at http:// www.twdb.texas.gov/surfacewater/conditions/evaporation/ index.asp.

Turnipseed, D.P., and Sauer, V.B., 2010, Discharge measurements at gaging stations: U.S. Geological Survey Techniques and Methods, book 3, chap. A8, 87 p.

U.S. Geological Survey, 2015, National Water Information System: Accessed April 13, 2015, at http://waterdata.usgs. gov/tx/nwis/.

Winter, T.C., Harvey, J.W., Franke, O.L., and Alley, W.M., 1998, Ground water and surface water-A single resource: U.S. Geological Survey Circular 1139, 79 p., accessed March 31, 2015, at http://pubs.water.usgs.gov/circ1139.

Young, K.B., 1950, A comparative study of mean-section and mid-section methods for computation of discharge measurements: U.S. Geological Survey Open-File Report 53-277, 52 p., accessed April 24, 2015, at http://pubs.usgs. gov/of/1953/0277/report.pdf. 



\section{Appendixes}



Appendix 1. Calculation of estimated evaporative losses within reaches on the Colorado River in northwestern Burnet County, Texas, December 3-6, 2012.

[ft, feet; in/d, inch per day; ft/s, feet per second; $\mathrm{ft}^{3} / \mathrm{s}$, cubic feet per second]

\begin{tabular}{|c|c|c|c|c|c|c|c|}
\hline Reach & $\begin{array}{c}\text { Reach } \\
\text { length } \\
\text { (ft) }\end{array}$ & $\begin{array}{l}\text { Stream width } \\
\text { at upstream } \\
\text { boundary } \\
\text { of reach } \\
\text { (ft) }\end{array}$ & $\begin{array}{l}\text { Stream width } \\
\text { at downstream } \\
\text { boundary } \\
\text { of reach } \\
\text { (ft) }\end{array}$ & $\begin{array}{c}\text { Average } \\
\text { stream } \\
\text { width for } \\
\text { entire reach } \\
\text { (ft) }\end{array}$ & $\begin{array}{c}\text { Lake } \\
\text { evaporation }{ }^{1} \\
\text { (in/d) }\end{array}$ & $\begin{array}{l}\text { Lake } \\
\text { evaporation } \\
\text { applied to } \\
\text { the reach } \\
\text { (ft/s) }\end{array}$ & $\begin{array}{c}\text { Estimated } \\
\text { evaporation } \\
\text { loss within } \\
\text { reach } \\
\left(\mathrm{ft}^{3} / \mathbf{s}\right)^{2}\end{array}$ \\
\hline A & 4,013 & 99 & 152 & 125.5 & 0.07419 & 0.0000000716 & 0.08 \\
\hline B & 9,662 & 152 & 137 & 144.5 & 0.07419 & 0.0000000716 & 0.23 \\
\hline $\mathrm{D}$ & 7,973 & 219 & 235 & 227 & 0.07419 & 0.0000000716 & 0.30 \\
\hline $\mathrm{E}$ & 7,762 & 235 & 301 & 268 & 0.07419 & 0.0000000716 & 0.35 \\
\hline $\mathrm{F}$ & 16,526 & 301 & 330 & 315.5 & 0.07419 & 0.0000000716 & 0.87 \\
\hline
\end{tabular}

${ }^{1}$ Texas Water Development Board, 2014, Precipitation and lake evaporation, accessed on December 19, 2014, at http://www.twdb.texas.gov/surfacewater/ conditions/evaporation/index.asp.

${ }^{2}$ A dimensionless daylight factor of 2.34 was used to calculate the estimated evaporation loss within each reach for measurements made during the fall 2012 (December 3-6, 2012) gain-loss survey. The dimensionless daylight factor is the ratio of 24 hours to the hours of daylight as described in Ockerman (2002, p. 7) 


\section{Streamflow Gains and Losses in the Colorado River in Northwestern Burnet and Southeastern San Saba Counties, Texas}

Appendix 2. Calculation of estimated evaporative losses within reaches on the Colorado River in northwestern Burnet County, Texas, May 31-June 1, 2014.

[ft, feet; in/d, inch per day; ft/s, feet per second; ftºs, cubic feet per second]

\begin{tabular}{|c|c|c|c|c|c|c|c|}
\hline Reach & $\begin{array}{c}\text { Reach } \\
\text { length } \\
\text { (ft) }\end{array}$ & $\begin{array}{l}\text { Stream width } \\
\text { at upstream } \\
\text { boundary of } \\
\text { reach } \\
\text { (ft) }\end{array}$ & $\begin{array}{l}\text { Stream width } \\
\text { at downstream } \\
\text { boundary } \\
\text { of reach } \\
\text { (ft) }\end{array}$ & $\begin{array}{c}\text { Average } \\
\text { stream width } \\
\text { for entire reach } \\
\text { (ft) }\end{array}$ & $\begin{array}{c}\text { Lake } \\
\text { evaporation } \\
\text { (in/d) }\end{array}$ & $\begin{array}{l}\text { Lake evaporation } \\
\text { applied to } \\
\text { the reach } \\
\text { (ft/s) }\end{array}$ & $\begin{array}{c}\text { Estimated } \\
\text { evaporation loss } \\
\text { within reach } \\
\left(\mathrm{ft}^{3} / \mathbf{s}\right)^{2}\end{array}$ \\
\hline A & 4,013 & 265.5 & 202 & 233.75 & 0.1899 & 0.000000183 & 0.29 \\
\hline B.1 & 3,326 & 202 & 216 & 209 & 0.1899 & 0.000000183 & 0.22 \\
\hline B. 2 & 3,221 & 216 & 225.5 & 220.75 & 0.1899 & 0.000000183 & 0.22 \\
\hline B. 3 & 3,115 & 225.5 & 249 & 237.25 & 0.1899 & 0.000000183 & 0.23 \\
\hline C. 1 & 3,590 & 249 & 247 & 248 & 0.1899 & 0.000000183 & 0.28 \\
\hline C. 2 & 1,848 & 247 & 279 & 263 & 0.1899 & 0.000000183 & 0.15 \\
\hline D.1 & 2,534 & 279 & 288 & 283.5 & 0.1899 & 0.000000183 & 0.23 \\
\hline D.2 & 4,118 & 288 & 306 & 297 & 0.1899 & 0.000000183 & 0.38 \\
\hline D.3 & 1,320 & 306 & 288 & 297 & 0.1899 & 0.000000183 & 0.12 \\
\hline E & 7,762 & 288 & 324 & 306 & 0.1899 & 0.000000183 & 0.75 \\
\hline $\mathrm{F}$ & 16,526 & 324 & 469 & 396.5 & 0.1899 & 0.000000183 & 2.06 \\
\hline
\end{tabular}

${ }^{1}$ Texas Water Development Board, 2014, Precipitation and lake evaporation, accessed on December 19, 2014, at http://www.twdb.texas.gov/surfacewater/ conditions/evaporation/index.asp.

${ }^{2} \mathrm{~A}$ dimensionless daylight factor of 1.72 was used to calculate the estimated evaporation loss within each reach for measurements made during the spring 2014 (May 31-June 1, 2014) gain-loss survey. The dimensionless daylight factor is the ratio of 24 hours to the hours of daylight as described in Ockerman (2002, p. 7).

Publishing support provided by

Lafayette Publishing Service Center

Information regarding water resources in Texas is available at

http://tx.usgs.gov/ 


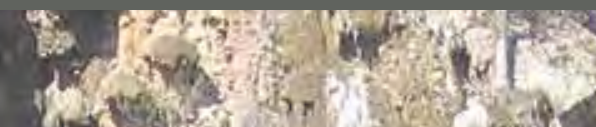

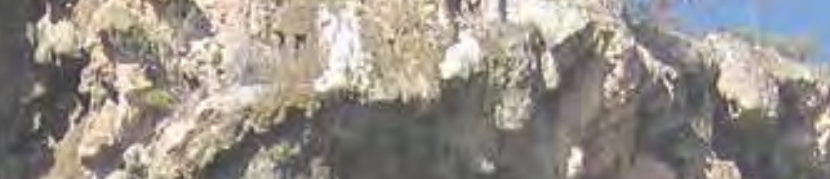
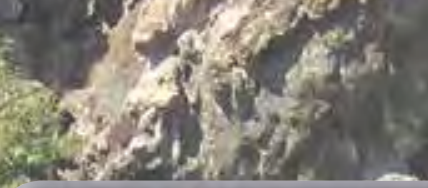
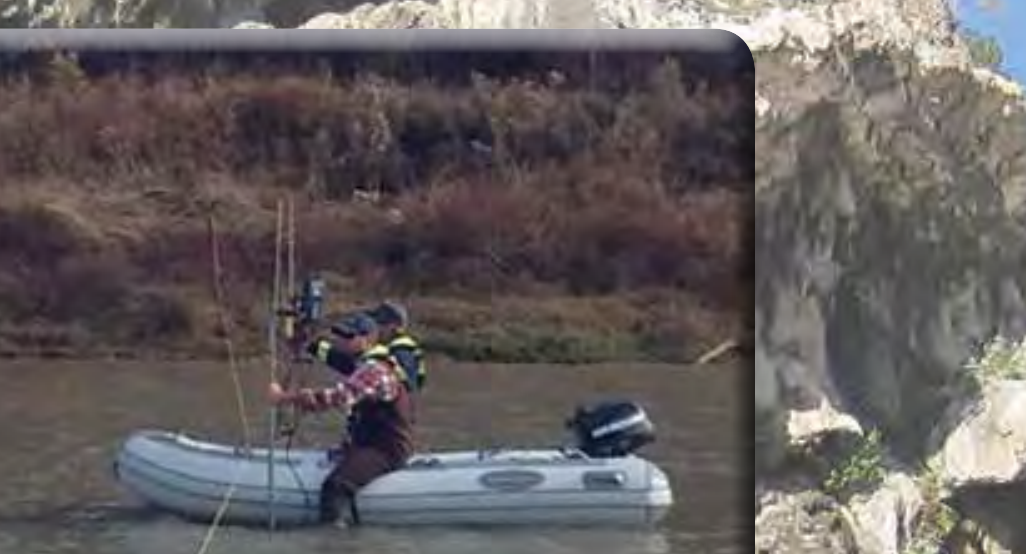

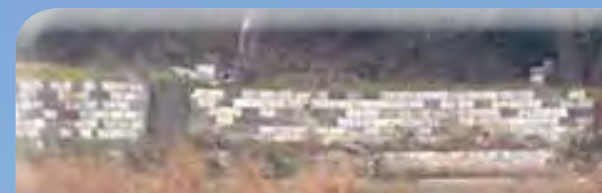
$7 \times 4=$
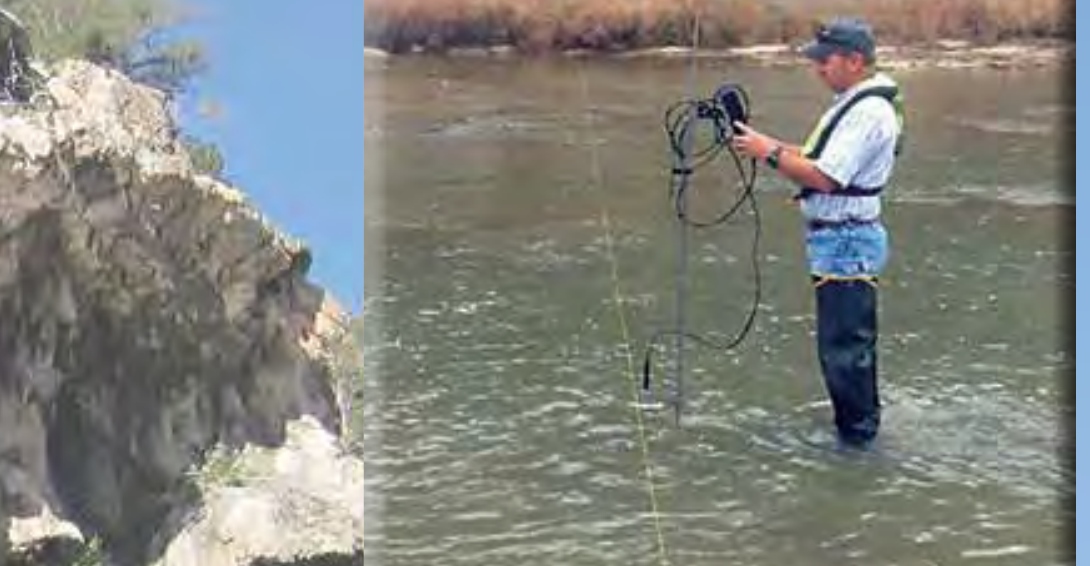

ris los

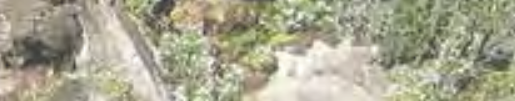

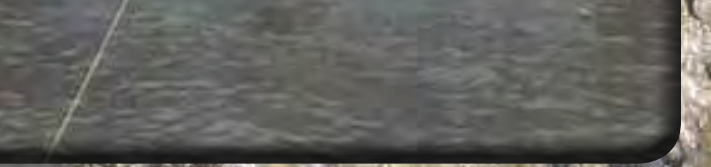

(1)

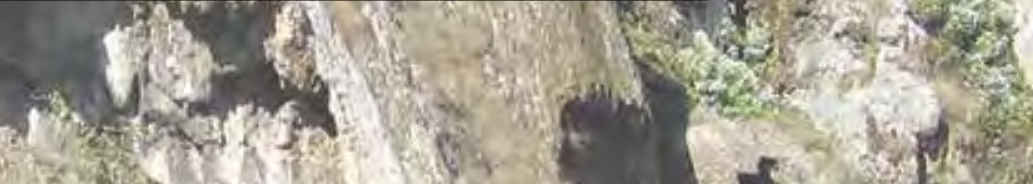

The 10

3.

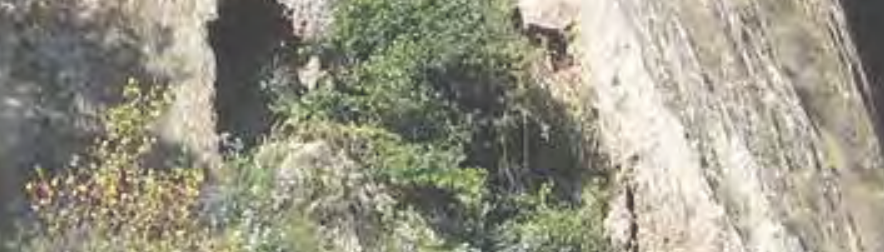

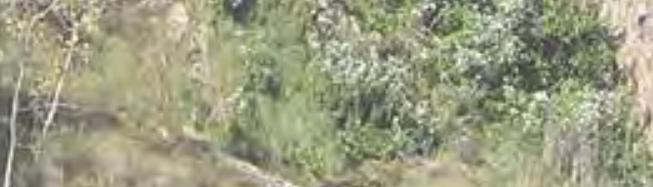
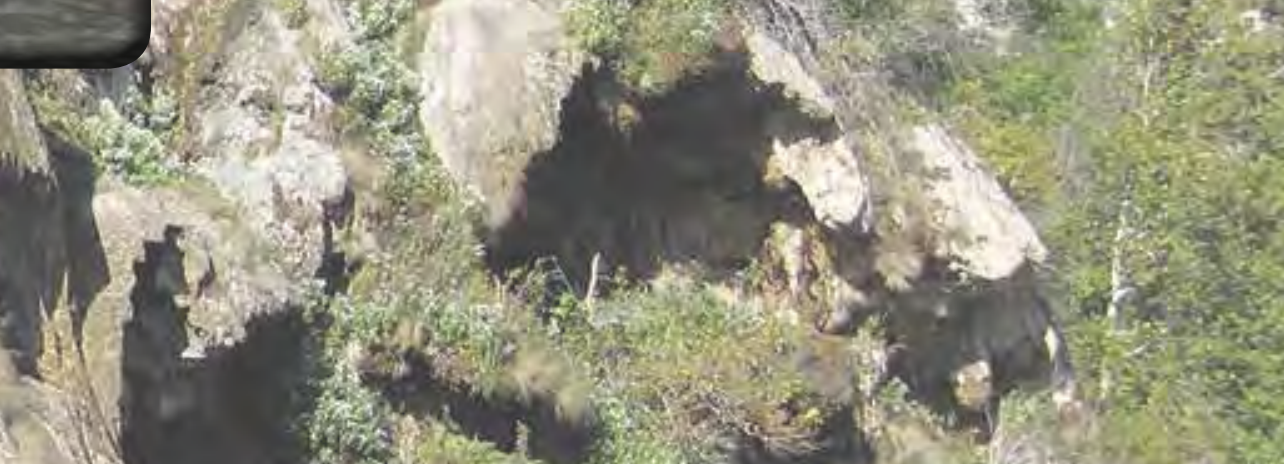

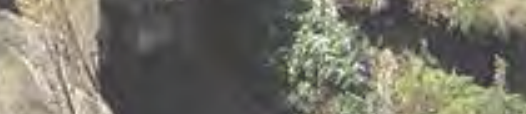
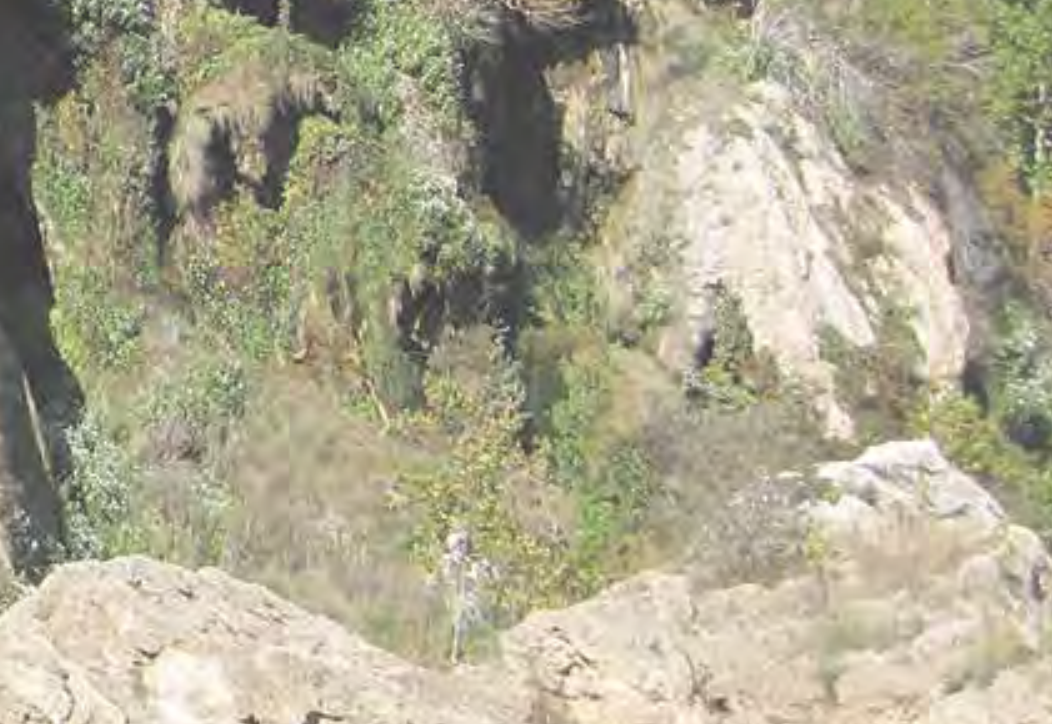

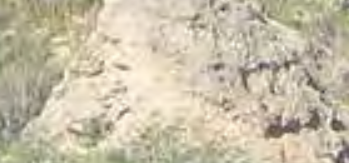

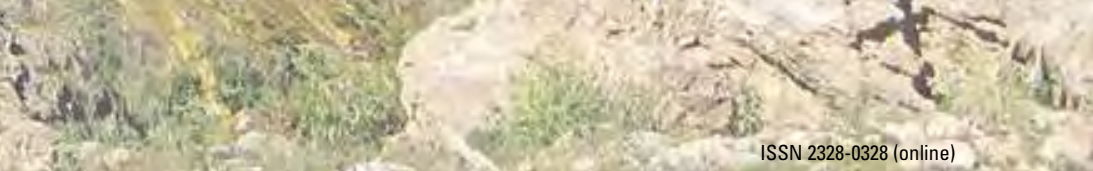

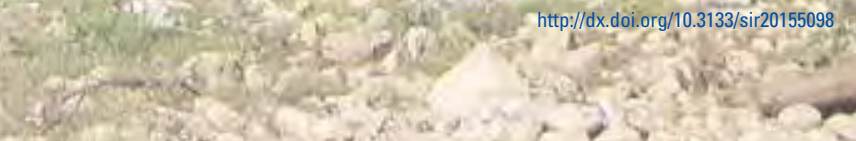

